\title{
Holocene Eruptive History of Shiveluch Volcano, Kamchatka Peninsula, Russia
}

\author{
Vera Ponomareva ${ }^{1}$, Philip Kyle ${ }^{2}$, Maria Pevzner ${ }^{3}$, \\ Leopold Sulerzhitsky ${ }^{3}$, and Melanie Hartman ${ }^{2}$
}

The Holocene eruptive history of Shiveluch volcano, Kamchatka Peninsula, has been reconstructed using geologic mapping, tephrochronology, radiocarbon dating, XRF and microprobe analyses. Eruptions of Shiveluch during the Holocene have occurred with irregular repose times alternating between periods of explosive activity and dome growth. The most intense volcanism, with frequent large and moderate eruptions occurred around 6500-6400 BC, 2250-2000 BC, and 50-650 $\mathrm{AD}$, coincides with the all-Kamchatka peaks of volcanic activity. The current active period started around $900 \mathrm{BC}$; since then the large and moderate eruptions has been following each other in 50-400 yrs-long intervals. This persistent strong activity can be matched only by the early Holocene one.

Most Shiveluch eruptions during the Holocene produced medium-K, hornblendebearing andesitic material characterized by high $\mathrm{MgO}$ (2.3-6.8 wt \%), $\mathrm{Cr}$ (47-520 ppm), Ni (18-106 ppm) and Sr (471-615 ppm), and low Y (<18 ppm). Only two mafic tephras erupted about 6500 and $2000 \mathrm{BC}$, each within the period of most intense activity.

Many past eruptions from Shiveluch were larger and far more hazardous then the historical ones. The largest Holocene eruption occurred $\sim 1050 \mathrm{AD}$ and yielded $>2.5 \mathrm{~km}^{3}$ of tephra. More than 10 debris avalanches took place only in the second half of the Holocene. Extent of Shiveluch tephra falls exceeded $350 \mathrm{~km}$; travel distance of pyroclastic density currents was $>22 \mathrm{~km}$, and that of the debris avalanches $\leq 20 \mathrm{~km}$.

\section{INTRODUCTION}

Large explosive eruptions can have a profound impact on the environment and seriously affect human lives. At the

\footnotetext{
${ }^{1}$ Institute of Volcanology and Seismology, Petropavlovsk-Kamchatsky, Russia

2 Department of Earth and Environmental Science, New Mexico Institute of Mining and Technology, Socorro, New Mexico, USA

${ }^{3}$ Geological Institute, Moscow, Russia

Volcanism and Subduction: The Kamchatka Region Geophysical Monograph Series 172

Copyright 2007 by the American Geophysical Union. 10.1029/172GM19
}

same time, the eruptions document critical moments in the life of a magmatic system and provide valuable information on its conditions. Of special interest are volcanoes that have frequent large explosive eruptions during their lifetime.

Shiveluch volcano is located near the northern end of Central Kamchatka Depression (Fig. 1) and is one of the most active volcanoes on the Kamchatka Peninsula. The average magma discharge is $\sim 0.015 \mathrm{~km}^{3}$ year ${ }^{-1}$, an order of magnitude higher than typical of island arc volcanoes [Melekestsev et al. 1991; Davidson and DeSilva, 2000]. Shiveluch has experienced many flank failures with formation of large debris avalanches. These are likely a consequence of the high magma supply rate and repetitive dome formation [Ponomareva et al., 1998; Belousov et al., 


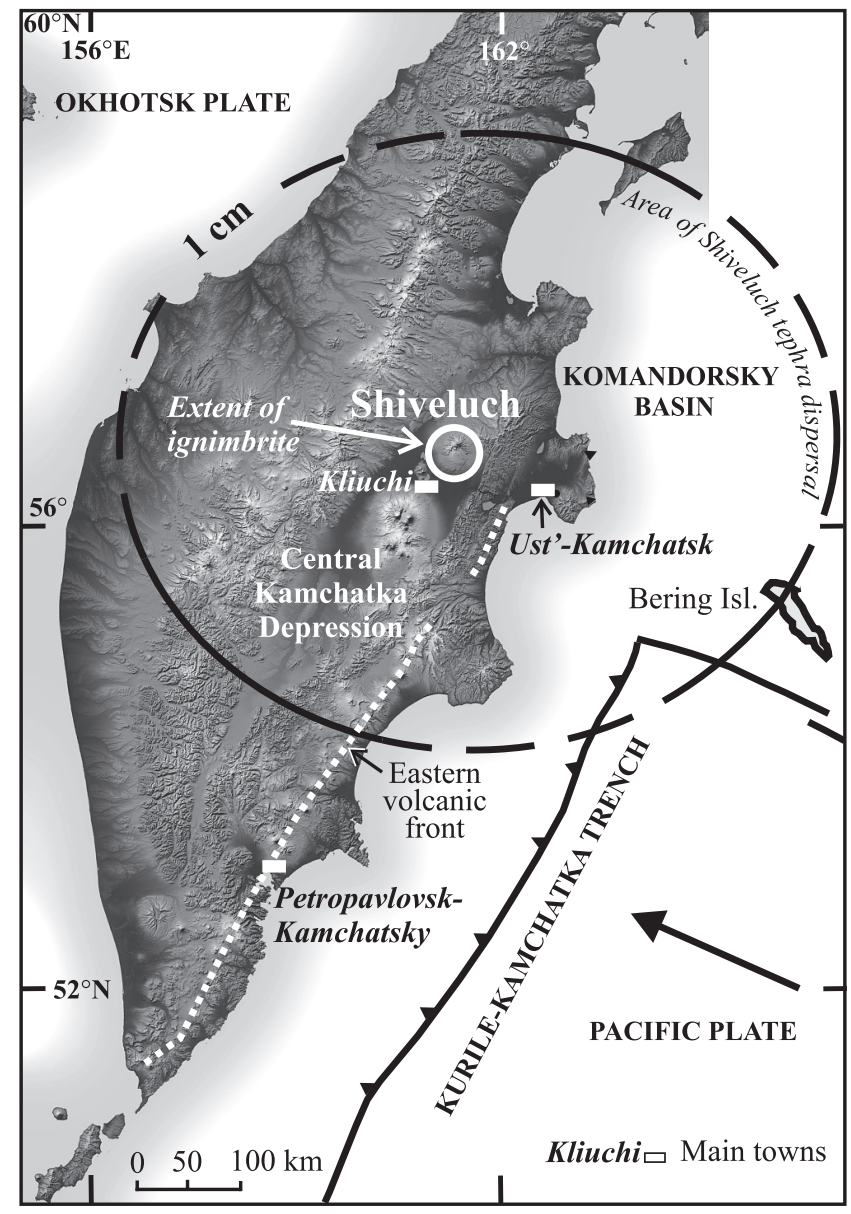

Figure 1. Map of Kamchatka showing the location of Shiveluch volcano and nearby towns of Kliuchi and Ust'-Kamchatsk. Shiveluch is located at the northern end of Central Kamchatka depression - a major graben structure located behind the Eastern volcanic front. The $1 \mathrm{~cm}$ limit for tephra erupted from Shiveluch is indicated. Base map is a shaded SRTM elevation model from NASA/JPL/NIMA.

1999]. Shiveluch mainly erupts high magnesium andesite, which has an adakitic character. Generation of the Shiveluch magmas may involve some slab melting as it is located over the edge of the subducting Pacific plate and warming or ablation of the slab by mantle flow may be responsible for magma generation [Volynets et al., 2000; Peyton et al., 2001; Yogodzinski et al., 2001; Park et al., 2002]. Numerous tephra layers erupted from Shiveluch serve as excellent markers in Holocene studies [Braitseva et al., 1997a; Pevzner et al., 1998]. Due to its frequent explosive eruptions, Shiveluch poses hazard not only to the towns of Kliuchi and Ust'Kamchatsk, located at a distance of $45-85 \mathrm{~km}$, but also for aviation. Everyday dozens of flights from Europe and North America to the Far East pass close to the Kamchatka
Peninsula and could easily intercept ash clouds from large eruptions of Shiveluch.

Good preservation of the Holocene deposits on the flanks and surrounding apron of Shiveluch has allowed us to reconstruct the last $\sim 10$ ka of eruptive activity using geologic mapping, tephrochronology, radiocarbon dating and geochemical analyses. Preliminary descriptions of a few individual eruptions were given by Volynets et al. [1997]; Ponomareva et al. [1998] and Pevzner et al. [1998]. In this paper we give a detailed account of the stratigraphy and composition of the Holocene deposits at Shiveluch volcano. 101 radiocarbon dates on paleosols, charcoal and wood samples are used to construct the eruptive history. We examine how activity has fluctuated with time and determine the duration of repose periods. This allows us to put the current ongoing activity into a historical perspective. We also briefly document the variation of magma composition with time and examine the potential hazards of eruptions from Shiveluch.

\section{GENERAL DESCRIPTION AND HISTORICAL ERUPTIONS}

Shiveluch volcano consists of a younger Holocene and older late Pleistocene eruptive centers (Figs. 2 and 3A, B). Young Shiveluch $(2,800 \mathrm{~m}$ a.s.1.) is a cluster of lava domes nested in a 9-km-wide collapse crater cut into the south side of the Old Shiveluch stratovolcano (3,283 $\mathrm{m}$ a.s.l.). The southward facing opening of the crater was likely controlled by a system of normal faults with vertical displacements of $\sim 500 \mathrm{~m}$ [Melekestsev et al., 1974]. Several Holocene lava domes were emplaced on the western slopes of Old Shiveluch. Most of the Holocene ignimbrites and debris avalanche deposits occur to the south of the volcano (Fig. 3A, B). The tephra-falls were dispersed in all directions depending on the prevailing wind at the time of eruption. Lahar deposits descend down all the radial valleys and form fans around the volcano. Old Shiveluch hosts summit and valley glaciers (Fig. 3B).

Written records of Shiveluch activity date back to 1739 [Gorshkov and Dubik, 1970]. In 1854 a large explosive eruption occurred [Ditmar, 1890]. This eruption deposited a voluminous pumice fall NNE of the volcano, moderate volumes of ignimbrite on the southern slope, and extensive lahar deposits that can be traced down all the valleys on the southern and western slopes [Ponomareva et al., 1998]. Smaller eruptions reported from 1879-1883, 1897-1898, 1905, 1928-1929 and 1944-1950, resulted in emplacement of lava domes with accompanying minor ash falls [Gorshkov and Dubik, 1970; Meniailov, 1955].

The most recent large eruption of Shiveluch occurred on November 12, 1964. It involved a sector collapse, subsequent phreatic explosion, a powerful plinian eruption resulting 
in fall and ignimbrite deposits and accompanying lahars [Gorshkov and Dubik, 1970; Belousov, 1995]. Lava domes have been growing in the 1964 crater since 1980, occasionally producing block-and-ash and pumice flows, landslides, and minor ash falls, most recently in 2007 [Dvigalo, 1984; Gorelchik et al., 1997; Khubunaya et al., 1995; Zharinov et al., 1995; Fedotov et al., 2004; http://www.kcs.iks.ru/ivs/ kvert/volcanoes/Sheveluch/index_eng.html]. The 2005 eruptions were the largest since 1964 but they still rank below the latter in magnitude.

\section{TYPES OF SHIVELUCH DEPOSITS}

Holocene volcanic deposits, interlayered with paleosol horizons, form a soil-pyroclastic sequence on the slopes and foot of Shiveluch which has been continuously accumulating during the last $\sim 10 \mathrm{ka}$ (Fig. 4). At distances $>7 \mathrm{~km}$ from the crater, the Holocene deposits include tephra fall, pyroclastic density current deposits, debris avalanche and debris flow (lahar) units. They are underlain by assorted glacial or pre-Holocene debris avalanche deposits. The Holocene deposits are well exposed in a number of deep radial valleys (Figs. 3 and 4).

Tephra fall deposits. Typical proximal tephra fall deposits at Shiveluch are andesitic pumice lapilli tuffs produced by Plinian eruptions (Fig. 4A, B; Table 1). In more distal localities the pumice lapilli transition into coarse ash, commonly enriched in mineral grains and basaltic andesitic in composition, and then to a fine dominantly vitric andesiticdacitic ash [Braitseva et al., 1997a]. Many fall units have distinct dispersal axes, e.g. tephras shown at Figure 5A, which depend on the wind direction at the time of eruption. Such fall deposits are usually unstratified and ungraded (Fig. 4A) and were likely emplaced continuously over a short time interval. Some pumice fall layers have wider dispersal directions (Fig. 5B, C) possibly due to varying wind directions and they have normal or reverse grading (Fig. 4B). The largest fall deposits have estimated volumes of $2-3 \mathrm{~km}^{3}$ and their $1 \mathrm{~cm}$ isopachs reach $\sim 350 \mathrm{~km}$ downwind from the eruptive center. This is about the limit that the tephra can be recognized in the soil-pyroclastic cover (Fig. 1). Other types of tephra fall deposits include: 1) those associated with explosions on lava domes (commonly fine to coarse dark-pink or pale ash); 2) co-ignimbrite falls (very fine white vitric ash); and 3) those produced by phreatic eruptions (gray fine matrix commonly enriched in rock fragments). These tephra fall deposits normally are less voluminous than the Plinian ones.

Two Shiveluch tephra layers are mafic in composition and differ from the typical andesite tephra [Volynets et al., 1997]. The older one is informally called the "dark package" and is a dark-gray stratified coarse ash and small lapilli of

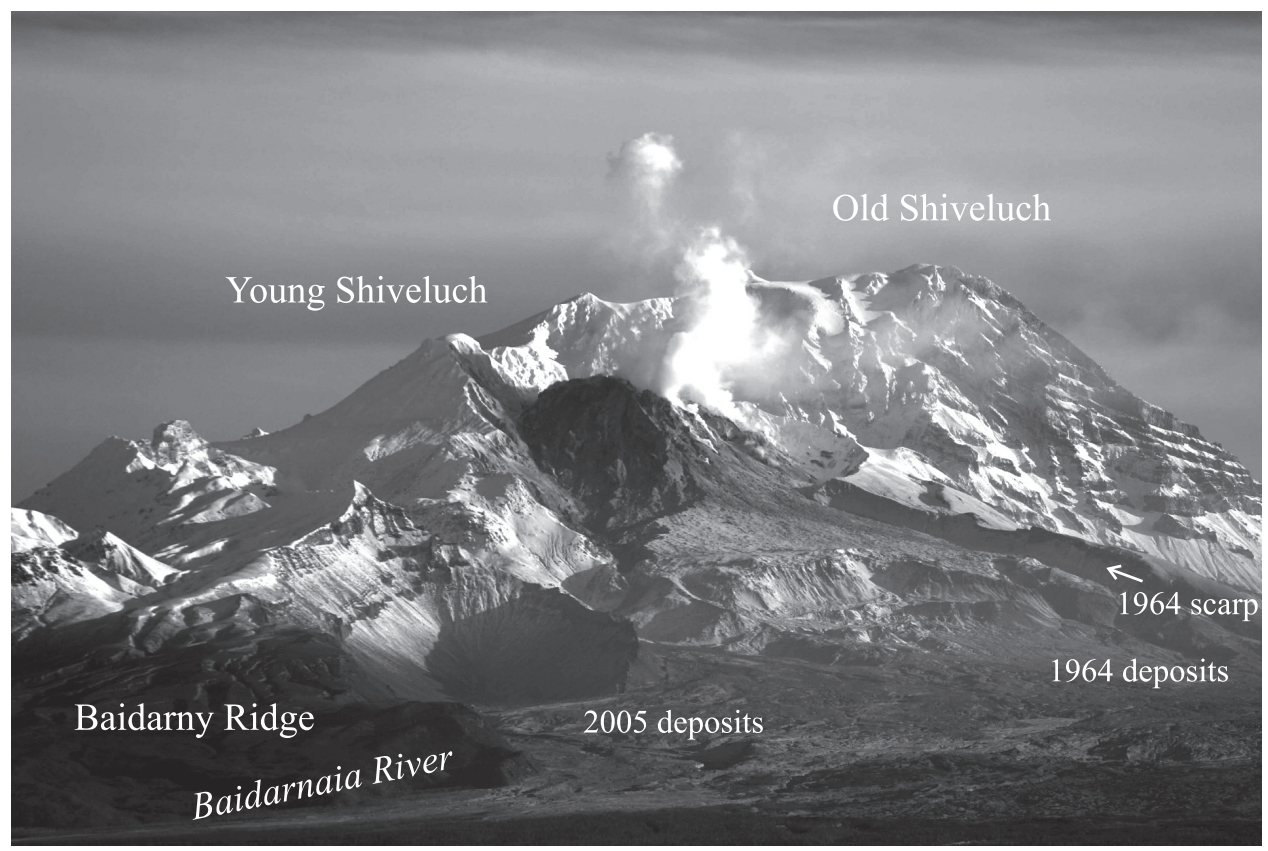

Figure 2. View of Shiveluch looking northeast showing the older snow covered Pleistocene volcano and in front the mainly Holocene Young Shiveluch. The current active andesite lava dome has a gas plume and is surrounded to the south by an apron of young deposits many resulting from the 1964 and subsequent eruptions. Photo taken by Yuri Demianchuk in October, 2005. 


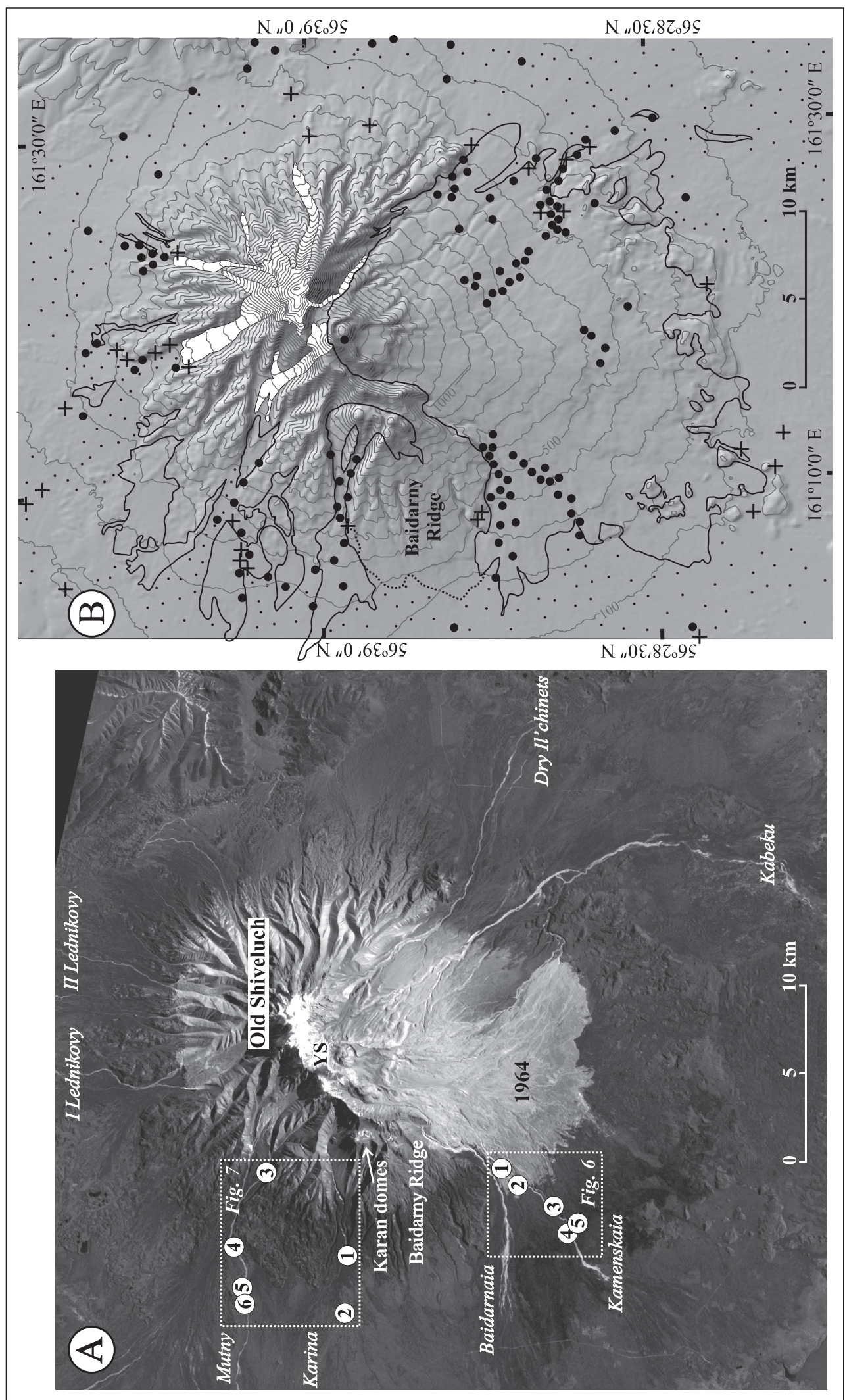

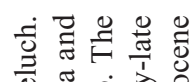

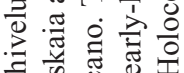
की

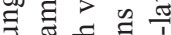

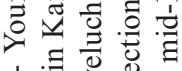

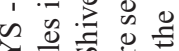

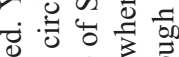

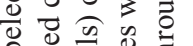

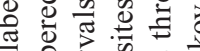

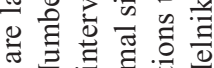

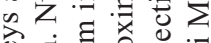

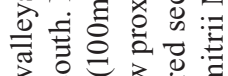

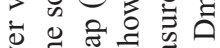

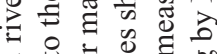

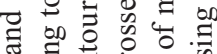
w

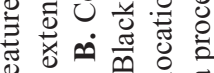
응 글 on

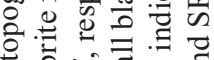

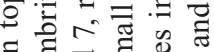

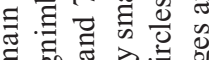
घ. 해응

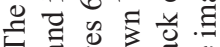
.

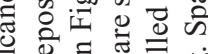

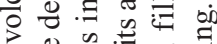

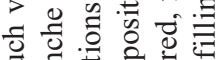
吾志

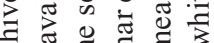

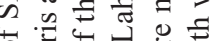
영 岁 눙 品 记

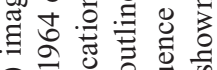
I 0 응

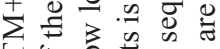

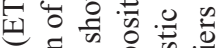

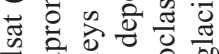
政

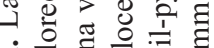

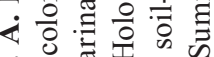

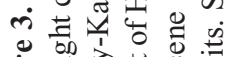

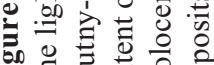

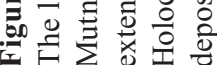


Table 1. Representative Whole Rock Major and Trace Element Analyses of Pumice Clasts from Shiveluch

\begin{tabular}{|c|c|c|c|c|c|c|c|c|c|c|c|c|}
\hline $\begin{array}{l}\text { Eruption } \\
\text { number }\end{array}$ & $1\left(\mathrm{SH}_{1964}\right)$ & 8 & 16 & 18 & 25 & 28 (SHsp) & 29 & 32 & 39 & 46 & 47 & 58 \\
\hline $\mathrm{SiO}_{2}$ & 60.59 & 60.41 & 57.65 & 60.71 & 59.72 & 51.43 & 55.96 & 57.11 & 61.16 & 52.65 & 62.55 & 58.80 \\
\hline $\mathrm{TiO}_{2}$ & 0.54 & 0.54 & 0.66 & 0.50 & 0.54 & 0.83 & 0.60 & 0.62 & 0.53 & 0.72 & 0.48 & 0.63 \\
\hline $\mathrm{Al}_{2} \mathrm{O}_{3}$ & 16.59 & 16.39 & 16.42 & 16.67 & 16.30 & 13.69 & 14.93 & 15.73 & 16.69 & 15.21 & 16.67 & 16.43 \\
\hline $\mathrm{Fe}_{2} \mathrm{O}_{3}$ & 5.19 & 5.29 & 6.23 & 4.80 & 5.27 & 9.43 & 7.03 & 6.23 & 4.90 & 8.13 & 4.49 & 6.01 \\
\hline $\mathrm{MnO}$ & 0.10 & 0.10 & 0.12 & 0.09 & 0.10 & 0.16 & 0.12 & 0.11 & 0.10 & 0.14 & 0.09 & 0.11 \\
\hline $\mathrm{MgO}$ & 3.73 & 3.77 & 4.67 & 3.19 & 3.85 & 10.58 & 8.50 & 5.62 & 3.18 & 9.25 & 2.35 & 3.91 \\
\hline $\mathrm{CaO}$ & 5.97 & 5.91 & 6.54 & 5.47 & 5.83 & 8.36 & 7.22 & 6.52 & 5.72 & 7.77 & 5.12 & 6.23 \\
\hline $\mathrm{Na}_{2} \mathrm{O}$ & 4.59 & 4.51 & 4.35 & 4.66 & 4.30 & 2.71 & 3.67 & 4.02 & 4.55 & 3.14 & 4.40 & 4.20 \\
\hline $\mathrm{K}_{2} \mathrm{O}$ & 1.29 & 1.39 & 1.22 & 1.30 & 1.34 & 1.70 & 1.06 & 1.40 & 1.36 & 0.90 & 1.46 & 1.43 \\
\hline $\mathrm{P}_{2} \mathrm{O}_{5}$ & 0.17 & 0.18 & 0.21 & 0.17 & 0.18 & 0.36 & 0.16 & 0.20 & 0.18 & 0.17 & 0.18 & 0.20 \\
\hline L.O.I. & 0.47 & 0.92 & 1.44 & 2.09 & 1.85 & 0.78 & 0.23 & 1.41 & 1.89 & 1.17 & 2.02 & 1.78 \\
\hline Total & 99.22 & 99.42 & 99.51 & 99.65 & 99.27 & 100.03 & 99.50 & 98.98 & 100.25 & 99.25 & 99.80 & 99.73 \\
\hline S & 265 & 514 & 410 & 99 & 278 & 588 & 199 & 235 & 484 & 82 & 274 & 1200 \\
\hline $\mathrm{Cl}$ & 538 & 353 & 878 & 569 & 519 & 224 & 292 & 527 & 475 & 272 & 316 & 547 \\
\hline $\mathrm{V}$ & 116 & 106 & 129 & 98 & 106 & 261 & 165 & 127 & 106 & 233 & 70 & 122 \\
\hline $\mathrm{Cr}$ & 117 & 111 & 136 & 94 & 123 & 591 & 508 & 254 & 85 & 563 & 52 & 104 \\
\hline $\mathrm{Ni}$ & 29 & 30 & 45 & 25 & 33 & 157 & 146 & 61 & 25 & 173 & 15 & 27 \\
\hline $\mathrm{Cu}$ & 37 & 27 & 47 & 25 & 28 & 54 & 63 & 48 & 33 & 70 & 15 & 41 \\
\hline $\mathrm{Zn}$ & 54 & 51 & 60 & 52 & 55 & 77 & 64 & 61 & 58 & 74 & 54 & 59 \\
\hline $\mathrm{Ga}$ & 18 & 17 & 19 & 19 & 19 & 16 & 16 & 18 & 18 & 16 & 18 & 19 \\
\hline As & 7 & 7 & 5 & 6 & 6 & 2 & 3 & 5 & 6 & 4 & 6 & 6 \\
\hline $\mathrm{Rb}$ & 21 & 23 & 20 & 21 & 23 & 38 & 16 & 23 & 22 & 16 & 30 & 25 \\
\hline $\mathrm{Sr}$ & 556 & 580 & 539 & 568 & 537 & 482 & 459 & 552 & 586 & 393 & 544 & 528 \\
\hline $\mathrm{Y}$ & 13 & 14 & 16 & 12 & 13 & 21 & 14 & 14 & 13 & 16 & 12 & 17 \\
\hline $\mathrm{Zr}$ & 111 & 110 & 123 & 119 & 115 & 93 & 89 & 109 & 112 & 91 & 119 & 122 \\
\hline $\mathrm{Nb}$ & 2 & 1 & 2 & 2 & 2 & 2 & 2 & 1 & 2 & 3 & 2 & 2 \\
\hline Mo & 1 & 1 & 1 & 1 & 1 & 1 & $<1$ & $<1$ & 1 & $<1$ & 1 & 2 \\
\hline $\mathrm{Ba}$ & 408 & 465 & 399 & 431 & 447 & 467 & 341 & 473 & 404 & 328 & 456 & 443 \\
\hline $\mathrm{Pb}$ & 6 & 9 & 7 & 6 & 7 & 7 & 5 & 8 & 9 & 6 & 7 & 8 \\
\hline Th & 1 & 4 & 1 & $<1$ & $<1$ & 1 & $<1$ & $<1$ & 1 & 3 & $<1$ & 1 \\
\hline $\mathrm{U}$ & 1 & 2 & 1 & 2 & 1 & 1 & 1 & 1 & $<1$ & 1 & 1 & $<1$ \\
\hline
\end{tabular}

Analyses were made by XRF in New Mexico Institute of Mining and Technology, USA. Description of the analyzed samples: eruption number (sample number; facies of the deposit). 1 (00K69; ignimbrite); 8 (00K67; ignimbrite); 16 (00K50; fall); 18 (00K51; fall); 25 (00K55; fall); 28 (00K15; fall); 29 (00K22; ignimbrite); 32 (00K58; fall); 39 (00K30; fall); 46 (“dark package”, 97058/2; fall); 47 (00K32; fall); 58 (00K44; fall). Eruption codes of marker tephras are given in parentheses. In the text and on the diagrams we refer to contents of $\mathrm{SiO}_{2}$ in analyses, recalculated to $100 \%$, LOI free.

basaltic andesite composition (Table 1, eruption 46). The younger, coded SHsp, is a unique high-K, high-Mg olivine- and phlogopite-bearing basaltic lapilli tephra (Table 1, eruption 28) [Volynets et al., 1997].

Deposits of pyroclastic density currents are common at Shiveluch and are typically pumiceous ignimbrites (Fig. 4C) and various cross-bedded (surge) deposits. Most of these deposits directly overlie pumice fall units and likely formed as a result of a column collapse. We did not find block-andash flow deposits in any of our sections and found only a few minor non-pumiceous density current deposits likely derived from dome collapse. One ignimbrite (Table 1, eruption 29) is zoned from light andesitic pumice at the base to black mafic scoria on the top. Most of the ignimbrites were deposited south of the volcano but a few ignimbrites are found also on its western and northwestern slopes (Fig. 3B). The most distal ignimbrite (from $\mathrm{SH}_{1}$ eruption) occurs in the Kabeku Valley $22 \mathrm{~km}$ from the eruptive vent. The original extent of some ignimbrites was greater but they are buried at the extremities by younger lahar deposits. Most of the ignimbrites have volumes usually $<0.5 \mathrm{~km}^{3}$. A younger and extensive ignimbrite formed by $\mathrm{SH}_{1}$ eruption is $\leq 1 \mathrm{~km}^{3}$ (Fig. $5 \mathrm{~B}$ ).

Debris avalanche deposits. The most prominent debris avalanche on Shiveluch is late Pleistocene in age and resulted 

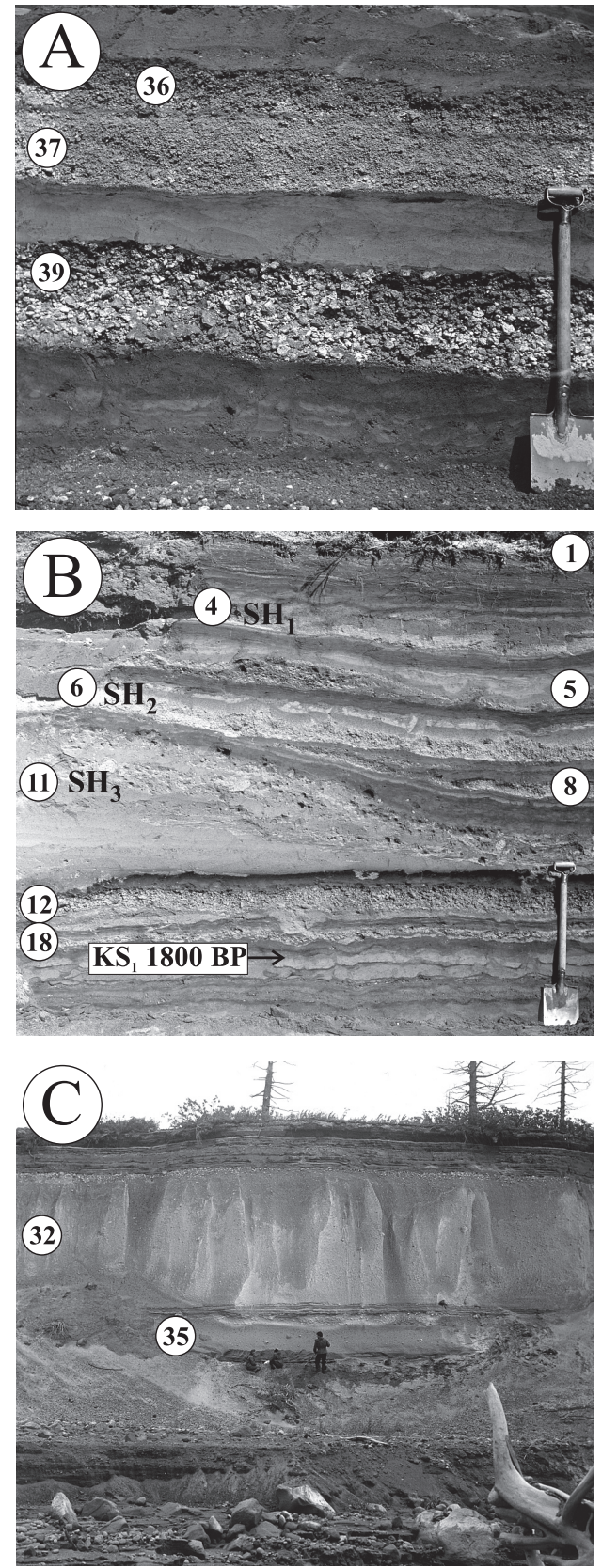

Figure 4. Selected sections showing the pyroclastic units around Shiveluch volcano. Units are labeled with their eruption numbers in white circles. A. Mid-Holocene pumice fall units interlayered with thin organic-rich paleosols and fine tephra $16 \mathrm{~km}$ southeast of the crater. A handle of a shovel is $\sim 50 \mathrm{~cm}$ long. B. Upper part of the soil-pyroclastic sequence $16 \mathrm{~km}$ southeast of the crater. Marker tephra layers $\mathrm{SH}_{1}, \mathrm{SH}_{2}$, and $\mathrm{SH}_{3}$ from Shiveluch and $\mathrm{KS}_{1}$ from Ksudach volcano are labeled. Note the wedge-shaped $\mathrm{SH}_{3}$ ignimbrite separating tephra-fall and paleosol layers. C. Coarsegrained ignimbrites interlayered between packages of tephra-fall and paleosol layers. SE sector, $14 \mathrm{~km}$ from the crater. A standing person is $\sim 180 \mathrm{~cm}$ tall. in the formation of the $9 \mathrm{~km}$-wide crater which dissects Old Shiveluch volcano. Large hummocks of this debris avalanche are found on the southern slope of the volcano (Fig. 3A) [Melekestsev et al., 1991; Belousov et al., 1999; Ponomareva et al., 2006]. More than 10 mid- to late Holocene debris avalanche deposits are exposed on the southern slope and 2 occur on the western slope of Shiveluch at distances $\geq 7$ $\mathrm{km}$ from the active vent [Ponomareva et al., 1998]. The prehistoric deposits are labeled with Roman numbers I-XIII (Figs. 6-10). Travel distances of individual Holocene avalanches exceeded $20 \mathrm{~km}$, and volumes reached $3 \mathrm{~km}^{3}$. When the avalanche deposits are not obscured by younger deposits they display a typical hummocky topography. Some debris avalanche deposits are completely buried under younger volcanic products but in outcrops they exhibit typical "block facies" often underlain by "mixed facies" [Glicken, 1986; Belousov et al., 1999]. When one considers the high magma discharge rates during the Holocene, it is likely there are more debris avalanche deposits which are not exposed or have not been identified.

In plan view most of the debris avalanche deposits look similar to the 1964 deposit which is narrow near vent and spreads out in a broad apron (Fig. 3A). These likely originated from a collapse of tightly spaced domes located close to the modern one. Debris avalanche deposits V and XII occur in a wide area extending from Baidarnaia to Dry Il'chinets Rivers (Fig. 3A) [Ponomareva et al., 1998]. This distribution suggests they originated from collapse of domes which once occupied the whole area of the late Pleistocene collapse crater. At least one of the deposits (X on Fig. 6) may have originated from Baidarny Ridge based on the dispersal of this deposit only in the southwestern sector of the volcano's foot and the presence of a collapse scarp on the ridge (Fig. 2). Ponomareva et al. [1998] gives more details on the distribution of the debris avalanche deposits and Belousov et al. [1999] provides characteristics of some of those.

Lahars (debris flows) likely accompanied most of Shiveluch eruptions due to the presence of glaciers and long-lived snow cover at the volcano. The lahar deposits have rounded rock fragments suspended in a coarse sandy matrix. They are exposed in all the valleys and merge into a discontinuous ring plain around the volcano (Fig. 3B).

\section{STRATIGRAPHY}

Our field work at Shiveluch has identified 60 large Holocene eruptions (Figs. 6-10). Eruptions are individually numbered but since tephra falls of 8 of them are distinct in some way and are used as markers, these eruptions are given the identifier code SH for Shiveluch [Braitseva et al., 1997a, b] (Table 2). 
At distances $>15 \mathrm{~km}$ from Shiveluch the Holocene soilpyroclastic sequence is dominated by pumice and ash falls separated by paleosols. Included in these sequences are regional marker tephra layers from volcanoes throughout Kamchatka (Figs. 4B, 6-10; Table 2). Studies of the historical deposits (e.g. those of the 1944-1950 and 1964 Shiveluch eruptions and the 1956 Bezymianny eruptions) show that even when there is a short time interval between eruptions, their deposits are separated by paleosols. Because the paleosols form rapidly, when volcanic deposits directly overlie each other and are not separated by paleosols, we have assigned them to the same eruption.

Most fall deposits erupted from Shiveluch look similar and are difficult to uniquely identify in many sections. Direct tracing of tephra layers from section to section was helpful. About 200 sections were measured around Shiveluch mostly along river valleys (Fig. 3B). In cases when correlation of the deposits from adjacent valleys was uncertain, pits up to 4-m-deep were dug on the divides to allow the tephra layers to be traced. All measured sections are over $7 \mathrm{~km}$ from the eruptive center. Early Holocene deposits are exposed $>10 \mathrm{~km}$ from the crater (Fig. 3B). For this reason our eruptive history only includes mid-late Holocene deposits, which reached distances $\geq 7 \mathrm{~km}$ from source and $10-12 \mathrm{~km}$ for early Holocene units. Some distal tephra falls from Shiveluch have been examined and dated in many sites throughout the Kamchatka Peninsula and are used as markers for volcanological, paleoseismological and paleoclimate research (e.g. Braitseva et al., 1983, 1991; Pevzner et al., 1998, 2006; Bourgeois et al., 2006; Kozhurin et al., 2006). These markers are included in Table 2; their ${ }^{14} \mathrm{C}$ ages are also shown on Figures $6-10$. We have used tephra thickness data from distal sites to construct isopach maps and estimate eruption volumes.

There is nearly continuous outcrop along the banks of rivers radiating out from Shiveluch. Significant differences can be seen in pyroclastic deposits from bank to bank along the rivers. So we therefore measured sections on both banks of each valley. Two examples of correlation of the sections down two river valleys are shown on Figures 6 and 7. Kamenskaia valley drains to the southwest and exposes deposits erupted during the last $\sim 1.5 \mathrm{ka}$ (Figs. 3A and 6). Mutny valley descends from Old Shiveluch to the northwest (Fig. 3A) exposing deposits erupted during the last $\sim 9.5 \mathrm{ka}$. As the pyroclastic sequence in Mutny valley is $>4 \mathrm{~m}$ thick, we show only the part between the $\mathrm{KS}_{1}$ and SHdv marker tephra layers (Fig. 7). Direct tracing of tephra layers and other deposits has allowed us to compile summary sections through the deposits exposed in each of

Figure 5. Representative isopach maps for Shiveluch eruptions showing the dispersal of $\mathrm{SH}_{1}, \mathrm{SH}_{2}$ and $\mathrm{SH}_{3}$ tephra fall units. Isopach are dashed where inferred and thicknesses are in $\mathrm{cm}$.
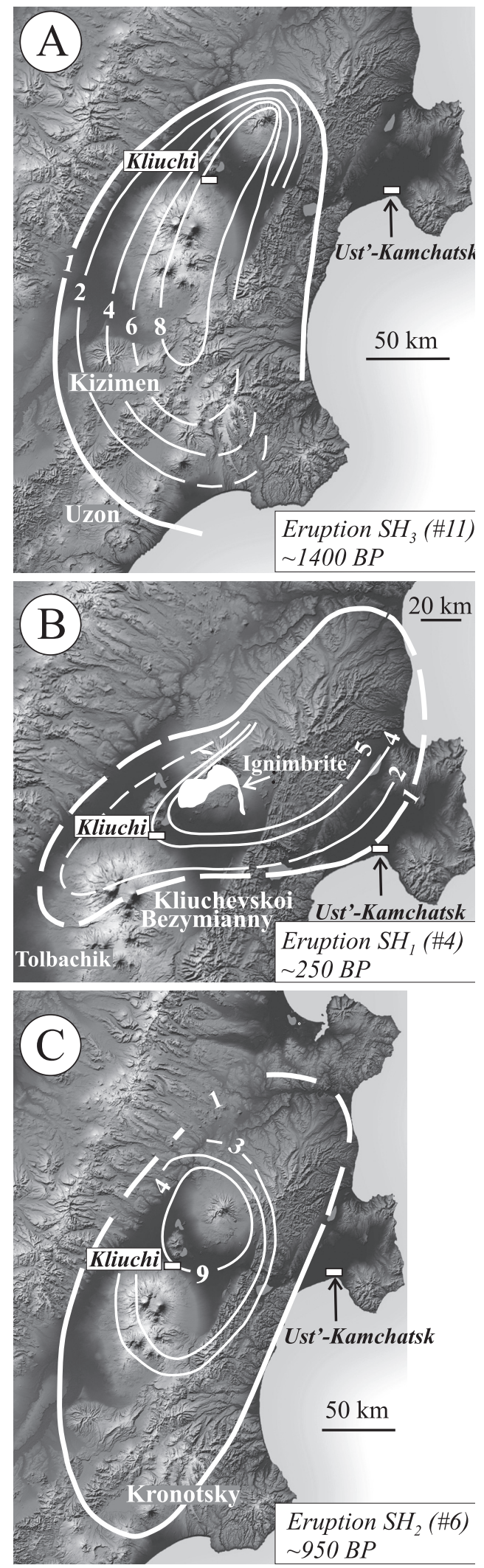
Table 2. Holocene Marker Tephra Layers Identified at Shiveluch Volcano, Kamchatka

\begin{tabular}{|c|c|c|c|c|c|}
\hline Source volcano & Code & $\begin{array}{l}\text { Rounded }{ }^{14} \mathrm{C} \text { age } \\
\text { (yr BP) }\end{array}$ & Description & Composition & Characteristic features \\
\hline Shiveluch & $\mathrm{SH}_{1964}$ & & White pumice lapilli & A & $\begin{array}{l}\text { Medium } \mathrm{K}_{2} \mathrm{O} \text { content, high } \mathrm{Cr} \text { and } \\
\mathrm{Sr} \text { content, presence of } \mathrm{Hb}, \mathrm{Ol}\end{array}$ \\
\hline Bezymianny & $\mathrm{B}_{1956}$ & & $\begin{array}{l}\text { Gray coarse to fine ash }(1-3 \\
\qquad \mathrm{cm})\end{array}$ & A & $\begin{array}{c}\text { Medium } \mathrm{K}_{2} \mathrm{O} \text { content, presence of } \\
\mathrm{Hb}\end{array}$ \\
\hline Shiveluch & $\mathrm{SH}_{1}$ & 250 & $\begin{array}{c}\text { Thinly stratified white fine to } \\
\text { coarse ash }\end{array}$ & A & $\begin{array}{l}\text { Medium } \mathrm{K}_{2} \mathrm{O} \text { content, high } \mathrm{Cr} \text { and } \\
\mathrm{Sr} \text { content, presence of } \mathrm{Hb}\end{array}$ \\
\hline “ & $\mathrm{SH}_{2}$ & 950 & $\begin{array}{l}\text { Normally graded light gray } \\
\text { coarse ash and pumice lapilli }\end{array}$ & A & $\begin{array}{l}\text { Medium } \mathrm{K}_{2} \mathrm{O} \text { content, high } \mathrm{Cr} \text { and } \\
\mathrm{Sr} \text { content, presence of } \mathrm{Hb}\end{array}$ \\
\hline “ & $\mathrm{SH}_{3}$ & 1400 & Dirty-yellow pumice lapilli & A & $\begin{array}{l}\text { Medium } \mathrm{K}_{2} \mathrm{O} \text { content, high } \mathrm{Cr} \text { and } \\
\text { Sr content, presence of } \mathrm{Hb}, \mathrm{Ol}\end{array}$ \\
\hline Ksudach & $\mathrm{KS}_{1}$ & 1800 & $\begin{array}{l}\text { Pale yellow (upper } 1-2 \mathrm{~cm} \\
\text { gray) fine ash }(6-8 \mathrm{~cm})\end{array}$ & $\mathrm{D}$ & Low $\mathrm{K}_{2} \mathrm{O}$ content, absence of $\mathrm{Hb}$ \\
\hline Shiveluch & $\mathrm{SH}_{5}$ & 2550 & $\begin{array}{l}\text { Yellow pumice lapilli in the } \\
\text { western sector and coarse } \\
\text { yellow ash in other sectors }\end{array}$ & A & $\begin{array}{l}\text { Medium } \mathrm{K}_{2} \mathrm{O} \text { content, high } \mathrm{Cr} \text { and } \\
\text { Sr content, presence of } \mathrm{Hb}, \mathrm{Ol}\end{array}$ \\
\hline “ & SHsp & 3600 & $\begin{array}{l}\text { Stratified dark-gray cinder } \\
\text { lapilli and coarse ash }\end{array}$ & B & $\begin{array}{c}\text { High } \mathrm{K}_{2} \mathrm{O}, \mathrm{MgO}, \mathrm{Cr} \text { and } \mathrm{Sr} \text { content, } \\
\text { presence of } \mathrm{Hb}, \mathrm{Ol} \text { and } \mathrm{Ph}\end{array}$ \\
\hline “ & SHdv & 4100 & $\begin{array}{l}\text { Normally graded pale yellow } \\
\text { coarse to fine ash }\end{array}$ & $\mathrm{A}$ & $\begin{array}{l}\text { Medium } \mathrm{K}_{2} \mathrm{O} \text { content, high } \mathrm{Cr} \text { and } \\
\mathrm{Sr} \text { content, presence of } \mathrm{Hb}\end{array}$ \\
\hline Kliuchevskoi & $\mathrm{KL}$ & $5800-6000$ & Black coarse ash $(0.5-1.5 \mathrm{~cm})$ & BA & Medium $\mathrm{K}_{2} \mathrm{O}$ content \\
\hline Ksudach & $\mathrm{KS}_{2}$ & 6000 & $\begin{array}{l}\text { Iron-stained ochre fine ash } \\
\qquad(0.5 \mathrm{~cm})\end{array}$ & A & Low $\mathrm{K}_{2} \mathrm{O}$ content, absence of $\mathrm{Hb}$ \\
\hline Khangar & KHG & 6950 & $\begin{array}{l}\text { Bright yellow fine ash } \\
\qquad(3-4 \mathrm{~cm})\end{array}$ & $\mathrm{D}$ & $\begin{array}{l}\text { Medium-high } \mathrm{K}_{2} \mathrm{O} \text { content, } \\
\text { presence of } \mathrm{Bi} \text { and } \mathrm{Hb}\end{array}$ \\
\hline Kizimen & $\mathrm{KZ}$ & 7550 & Yellow fine ash $(1-2 \mathrm{~cm})$ & $\mathrm{D}$ & $\begin{array}{c}\text { Medium } \mathrm{K}_{2} \mathrm{O} \text { content, presence of } \\
\mathrm{Hb}\end{array}$ \\
\hline Plosky & PL & 8600 & Dark-brown coarse ash $(1 \mathrm{~cm})$ & $\mathrm{BA}$ & High $\mathrm{K}_{2} \mathrm{O}$ content \\
\hline Plosky & PL & $\sim 9500$ & Dark-brown coarse ash $(1 \mathrm{~cm})$ & BA & High $\mathrm{K}_{2} \mathrm{O}$ content \\
\hline
\end{tabular}

Note. Tephra layers are listed in chronological order. Ages are the rounded average radiocarbon ages from Braitseva et al [1988, 1995, 1997a, b] and Volynets et al. [1997]. In description average thicknesses of distal marker tephra layers in the Shiveluch area are given in parentheses. Composition of the tephra are A - andesite; BA-basaltic andesite; D - dacites; RD - rhyodacite; R - rhyolite. $\mathrm{Hb}$, hornblende; Ol, olivine; $\mathrm{Bi}$, biotite; $\mathrm{Ph}$, phlogopite.

these valleys. In the same way we compiled summary sections for each of the radial valleys (Fig. 8) and combined them into a summary section through the Holocene pyroclastic succession at Shiveluch foot (Fig. 9). The summary section is the basis for the reconstruction of the Shiveluch Holocene eruptive activity. ${ }^{14} \mathrm{C}$ dates obtained in different valleys complement each other and provide a detailed framework for timing the eruptions.

Reconstruction of the eruptive history of Shiveluch and an understanding of the repose periods can only be determined using sections measured along multiple river valleys. Eruptive units were dispersed in different directions and some of them are absent on the southern slope of the volcano traditionally visited by researchers. Belousov et al. [1999] examined the pyroclastics on the southern slope and concluded that the vol- cano produced only one strong eruption $\left(\mathrm{SH}_{3}\right)$ between 1600 and $1000 \mathrm{BP}$. Our data show that actually this period includes a period of enhanced activity with at least three more large eruptions in addition to the $\mathrm{SH}_{3}$ one (Figs. 9-10) with fallout axes directed to the $\mathrm{N}$ and $\mathrm{SE}$ (Fig. 8).

We think that the tephra layers younger than $\sim 9.5 \mathrm{ka}$ (eruption \#52, Fig. 9) are equally well preserved in all the sectors around Shiveluch. Older tephra have been examined in fewer outcrops which hampers an understanding of their dispersal and eruptive volumes. Smaller early Holocene debris avalanche deposits may also be buried under younger deposits. Debris avalanche deposits VII and XI and two pyroclastic density current deposits have been recognized only on the western slope and were likely associated with eruptions of the Karan domes (Figs. 9 and 10). 
The various facies of an eruption are given on Figure 10. At least 6 eruptions started with debris avalanches and then produced pumice falls and ignimbrites or surge deposits. Five debris avalanches were followed only by deposition of ignimbrite and only 2 by tephra falls. More than 20 eruptions produced fall and pyroclastic density current deposits. Eighteen eruptions produced only fall deposits including 14 andesitic pumice fall deposits, 2 phreatic tephras and 2 basaltic fall deposits.

\section{ERUPTION VOLUMES}

The 1964 eruption $\left(\mathrm{SH}_{1964}\right)$ produced $\sim 2 \mathrm{~km}^{3}$ of debris avalanche and $0.3-0.4 \mathrm{~km}^{3}$ each of fall deposits and ignimbrite [Gorshkov and Dubik, 1970]. As this was the last major eruption these deposits are easily identified around the volcano. The $\mathrm{SH}_{1964}$ tephra fall deposit can be traced SE downwind of the volcano to the Pacific coast. In the Ust'-Kamchatsk region (Fig. 1) the fall was 2-3 cm thick. Ash from the $\mathrm{SH}_{1964}$ eruption was also observed to fall at Bering Island (Fig. 1), $\sim 330 \mathrm{~km}$ from source [Gorshkov and Dubik, 1970]. Now only minor traces of this ash are found there. The 1964 eruption can serve as a model for a large eruption from Shiveluch but examination of pre-historic deposits shows that larger eruptions have occurred in the past.

Only approximate volumes for pre-historic ignimbrite, surge and debris avalanche deposits can be estimated since many are obscured by younger eruptives or are partly eroded. Furthermore, calculation of tephra fall vol-

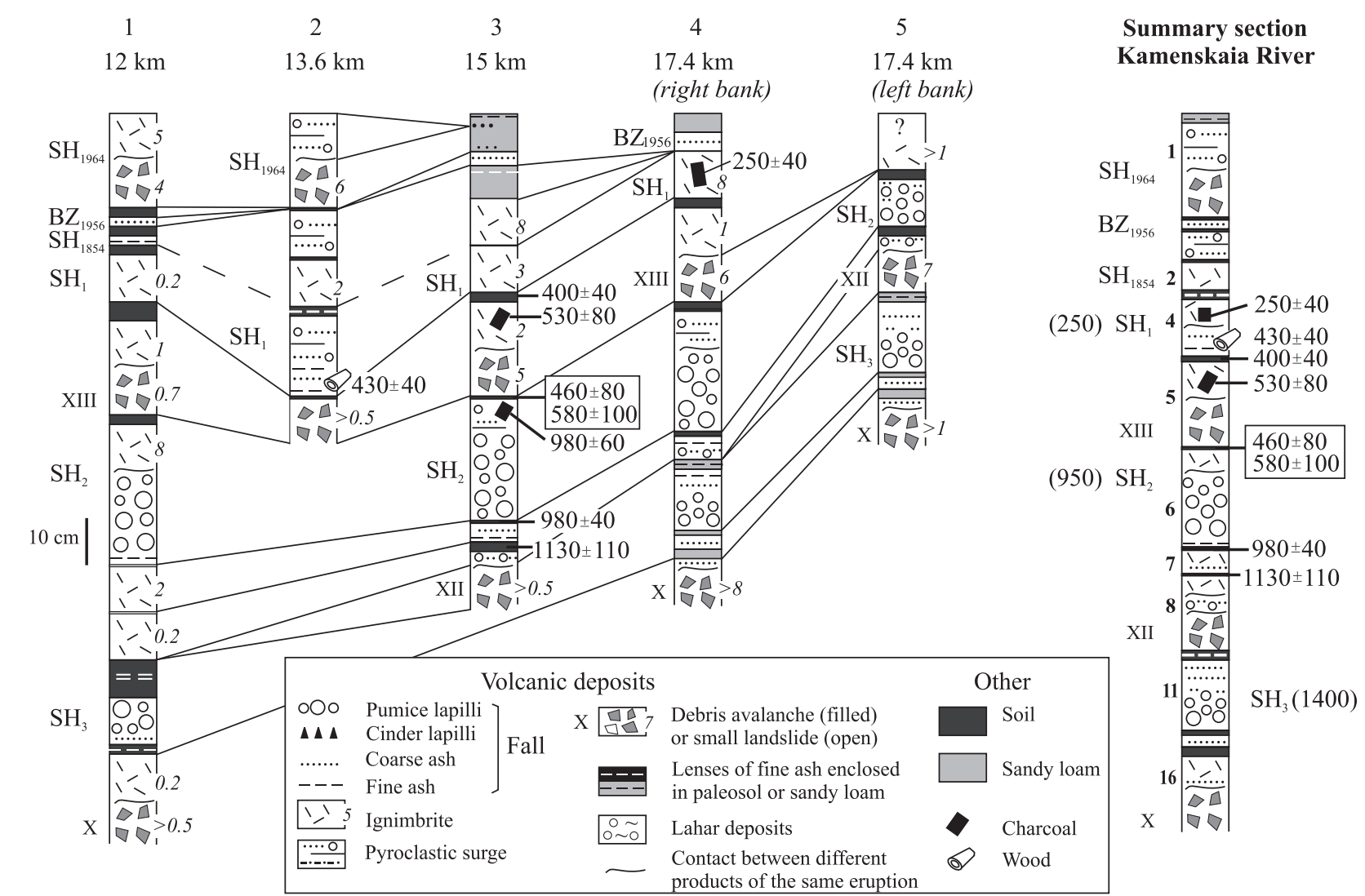

Figure 6. Summary and individual measured stratigraphic sections in the Kamenskaia River. Locations of the sections are shown on Figure 3A. Distance from the eruptive vent is shown above the columns. Inferred correlations are dashed. Rounded radiocarbon ages of marker tephra layers are given in the parentheses. Codes and ages of marker tephra layers as in Table 2. Roman numbers are debris avalanche deposits [from Ponomareva et al., 1998]. Radiocarbon dates obtained on successive alkaline extractions from the same sample are shown in boxes. See "Table 3" (available on the CD-ROM accompanying this volume). for details on the dated samples. The 10-cm scale (on the left) is for fall and surge deposits only. Lahar and debris avalanche deposits and ignimbrites are not to scale and their thicknesses in meters are shown to the right of the columns by italic numbers. Numbers of the eruptions are shown left of the summary section. 


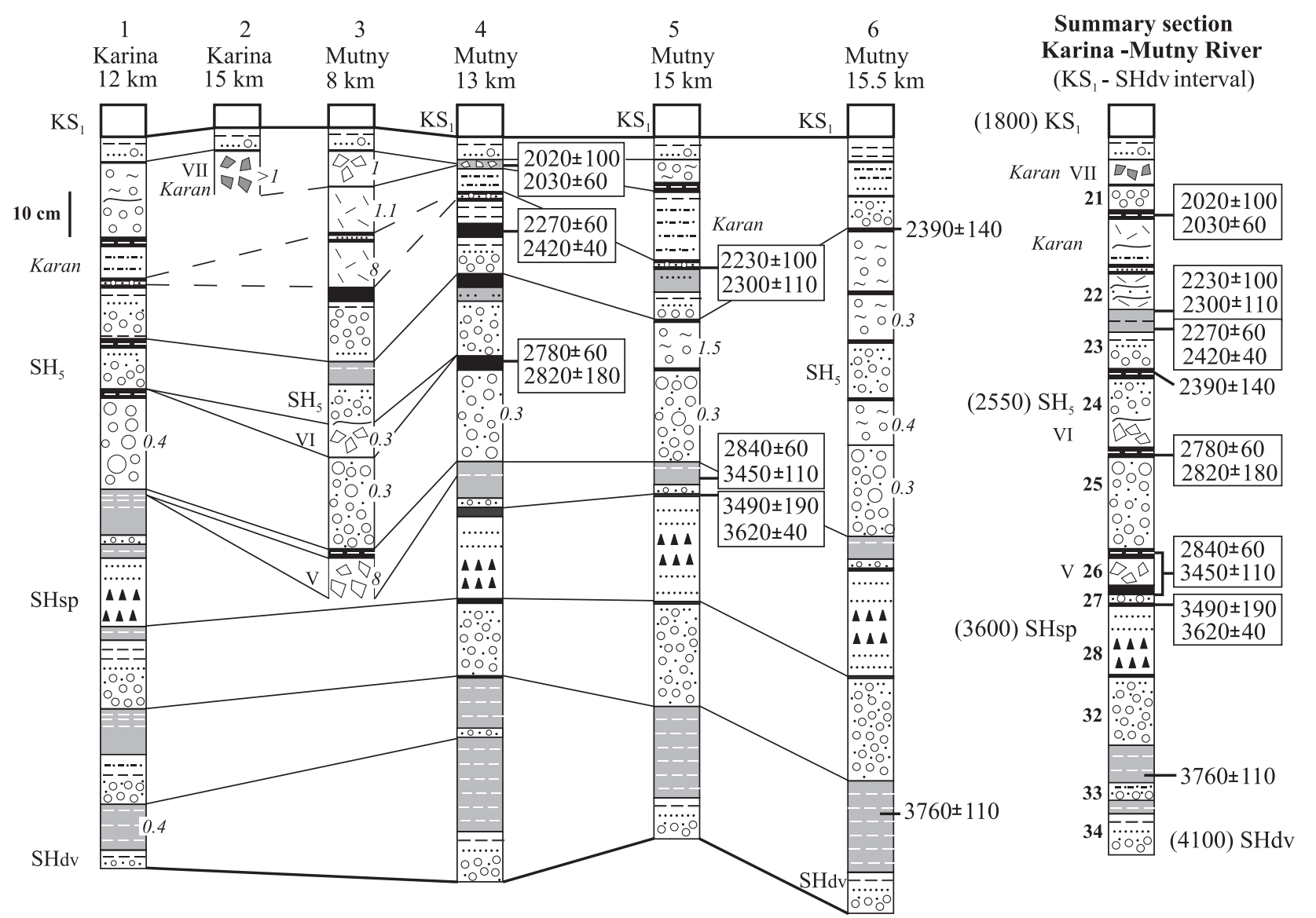

Figure 7. Summary and individual measured stratigraphic sections in the Karina and Mutny Rivers. Locations of the sections are shown on Figure 3A. Only the sections between the 1800 BP KS 1 and 4100 BP SHdv marker tephra layers are shown. Some deposits in these sections were probably erupted from the Karan domes and not from the main crater. Symbols are the same as Figure 6. Lahar deposits are not included into the summary section.

umes are hampered because identification and correlation of many distal deposits are difficult. Estimated volumes for the $\mathrm{SH}_{2}$ tephra show it is the largest tephra fall deposit (Fig. 5C). The $\mathrm{SH}_{1}$ eruption had the largest ignimbrite deposits and co-ignimbrite fall tephra (Fig. 5B). The smallest eruptions which are detectable $>7 \mathrm{~km}$ from the crater, are estimated to have tephra fall volumes of $\sim 0.01$ $\mathrm{km}^{3}$. Such small volume eruptions likely occurred during periods of dome growth. Here we use the 1964 eruption as a reference and classify eruptions with $>1 \mathrm{~km}^{3}$ of erupted products as the largest, $1-0.5 \mathrm{~km}^{3}$ as large, $0.5-0.1 \mathrm{~km}^{3}$ as moderate, and $<0.1 \mathrm{~km}^{3}$ as small or minor. For deposits erupted in historic times, including the Plinian eruptions in $1854\left(\mathrm{SH}_{1854}\right)$ and $1964\left(\mathrm{SH}_{1964}\right)$ and dome related eruptions in 1944-1950 and 1980-2005, we can calculate their volumes from field data. When these are compared to contemporary data on tephra dispersal, it shows that we tend to under-estimate the volumes of past eruptions.

\section{RADIOCARBON DATING}

Reconstructed eruptive history is based on 101 conventional radiocarbon dates on paleosols, charcoal and wood associated with the pyroclastic deposits (Table 3 available on the CD-ROM accompanying this volume; Fig. 9). Of those, sixteen dates have been earlier published by Ponomareva et al. [1998] and three dates - by Belousov et al. [1999]. The radiocarbon dates provide additional time constraints when used in conjunction with earlier dated marker tephras from Shiveluch and other volcanoes (Figs. 9 and 10; Table 2).

For radiocarbon dating, we used methods given in Braitseva et al. [1992, 1993], which can be summarized as follows. ${ }^{14} \mathrm{C}$ dates from soil layers, which formed over a long time interval, were obtained using successive alkaline extractions (Table 3: available on the CD-ROM accompanying this volume). In such cases we used the younger date for the soil underlying and the older date for the soil overlying the tephra 


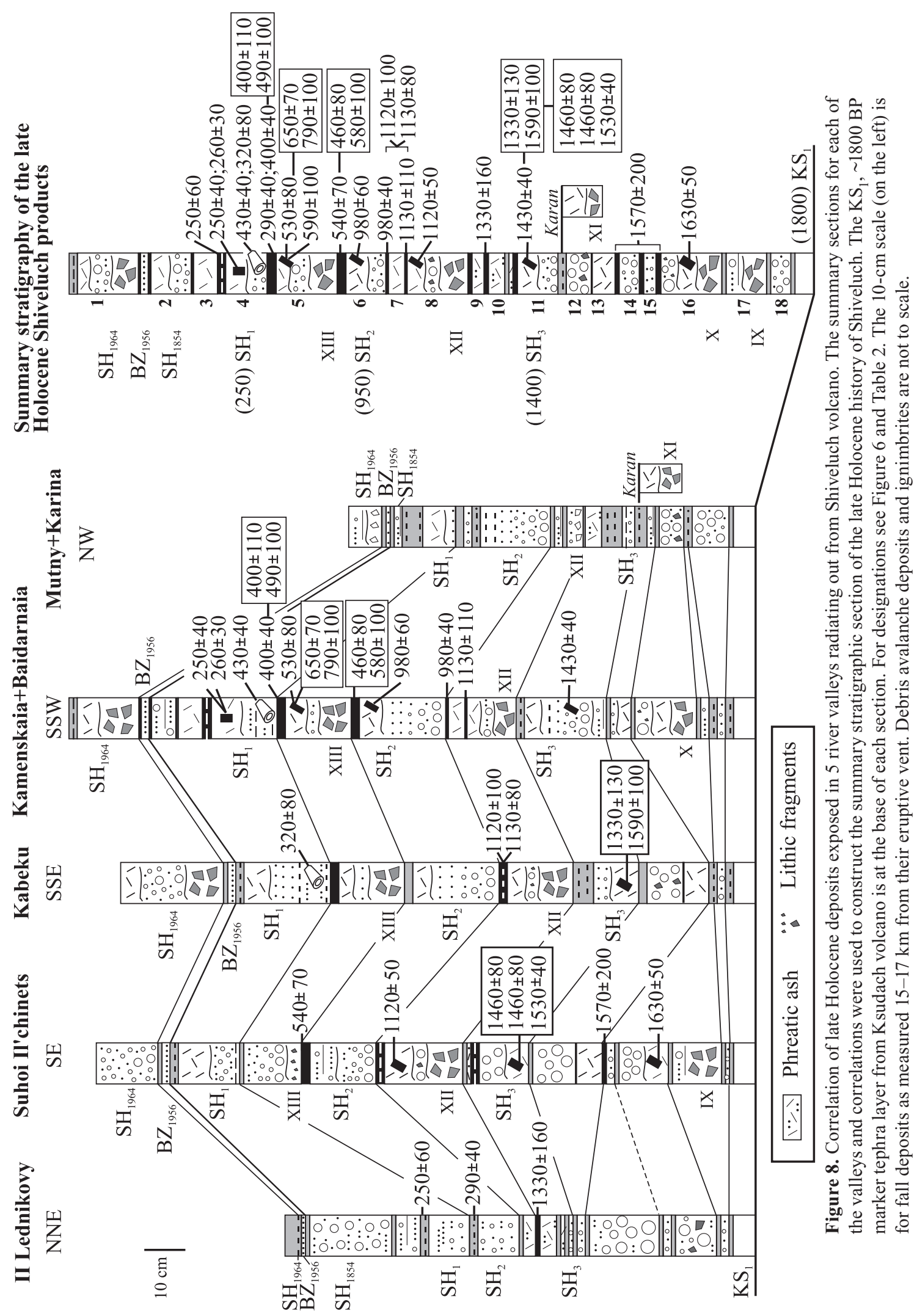




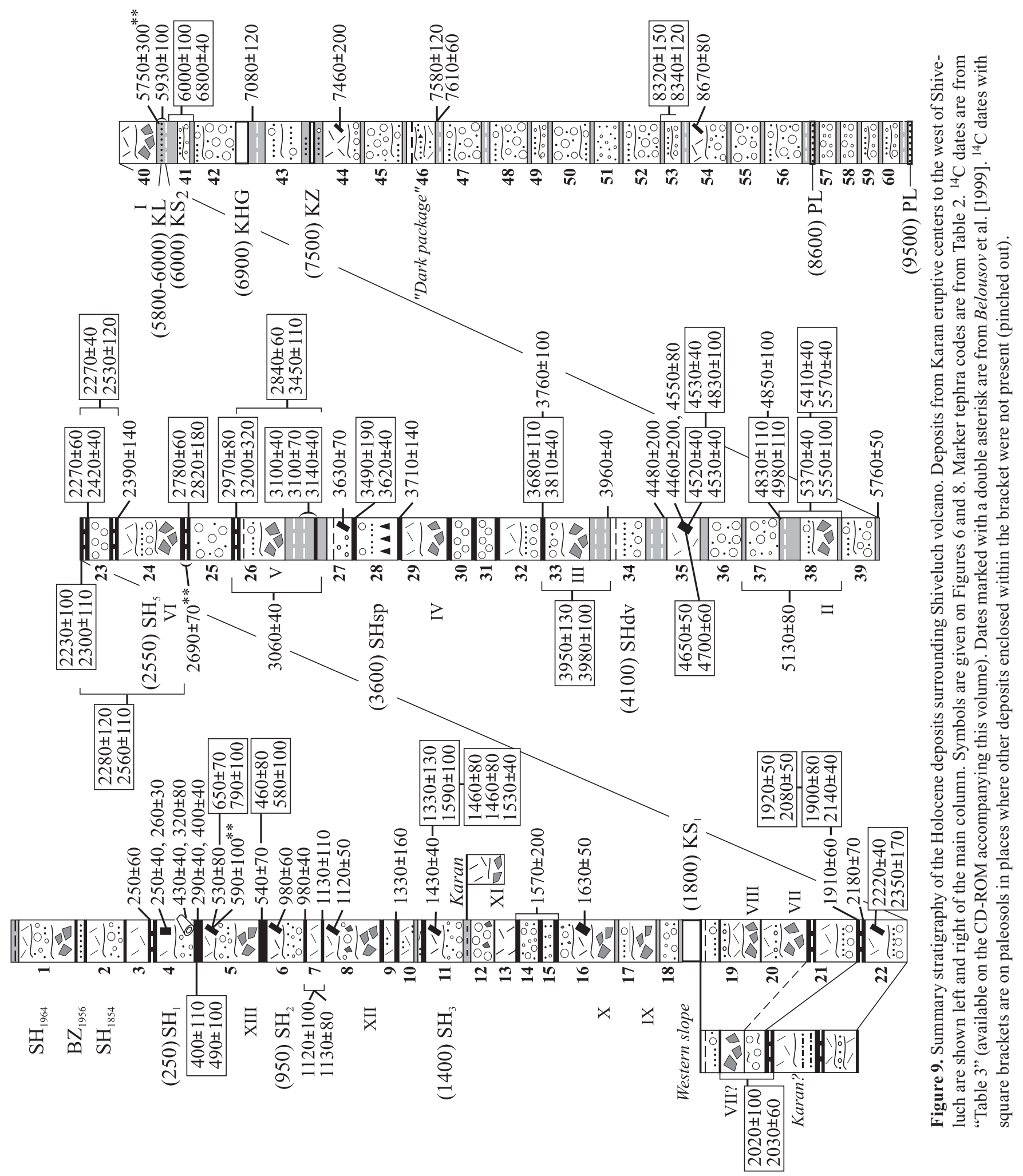


deposit. A date obtained on a long-lived soil or peat layer without subdivision into extractions gives its mean age and so may differ significantly from the age of under- or overlying deposits [Braitseva et al., 1993]. Wood found in debris avalanche deposits may have been redeposited and can yield older ages. The stratigraphic relationships and ages of the marker tephra layers also help to constrain the ${ }^{14} \mathrm{C}$ dating uncertainty. In Figures 6-8 we provide radiocarbon dates obtained in the individual valleys. In Figure 9 and in Table 3 (available on the CD-ROM accompanying this volume) we provide all the available dates. In Figure 10, we choose the dates we consider provide meaningful ages close to the ages of the eruptions. These are mainly dates on charcoal from the ignimbrites, and the youngest and the oldest dates on paleosols. Approximate ${ }^{14} \mathrm{C}$ ages were then estimated for each of the eruptions. For estimating the duration and timing of active and repose periods (Fig. 12) we have calibrated the ${ }^{14} \mathrm{C}$ ages using CALIB 5.0 [Stuiver et al., 2005]. In some parts of the summary stratigraphy, where the dates are rare or lacking (e.g. early Holocene, Fig. 10), we had to rely mostly on marker tephra layers and estimated the ages of individual eruptions dividing the age span between marker layers or between the calibrated dates by the number of the enclosed eruptions.

According to the requirements of the Radiocarbon http:// www.radiocarbon.org/Authors/author-info.pdf, we report radiocarbon dates as years BP (e.g., $1000 \mathrm{BP})$ and calibrated ages as years $\mathrm{BC}$ or $\mathrm{AD}$, or (only in Table 4 (available on the $\mathrm{CD}-\mathrm{ROM}$ accompanying this volume)) as cal years $\mathrm{BP}$.
Approximate age estimates in the running text, e.g. $\sim 10 \mathrm{ka}$, are calibrated ages as well.

\section{COMPOSITION OF ERUPTED PRODUCTS}

The major and trace element composition of ejecta from representative eruptions were determined by XRF (Table 1; Table 4 (available on the CD-ROM accompanying this volume)). All of these analyses are on pumice or scoria samples from pyroclastic deposits and should represent the bulk compositions of the magmas erupted at Shiveluch. Glasses from the tephra fall deposits were analyzed by electron microprobe to characterize their compositions and to allow them to be used in tephrochronological studies (Table 5).

Most Holocene erupted products are medium-K, hornblende-bearing andesites [Gill, 1981] having a range of $\mathrm{SiO}_{2}$ from 56 to $64 \%$ but many analyses have between 60 and $63 \% \mathrm{SiO}_{2}$ (Fig. 11A, B; Table 4 (available on the CD-ROM accompanying this volume)). The andesites are characterized by high-Mg olivines, which contain $\mathrm{Cr}$ spinel inclusions. Compared to other medium-K andesites in Kamchatka the andesite from Shiveluch has higher $\mathrm{Mg}$, $\mathrm{Ni}, \mathrm{Sr}$, and $\mathrm{Cr}$ contents and $\mathrm{Ni} / \mathrm{Co}, \mathrm{Cr} / \mathrm{V}$ and $\mathrm{Sr} / \mathrm{Y}$ ratios and lower Y contents [e.g., Churikova et al., 2001; Kepezhinskas et al., 1997; Melekestsev et al., 1991; Volynets et al., 1994, 1999; 2000; Yogodzinski et al., 2001]. The high Sr/Y ratios and low Y concentrations are typical of adakites [Defant and Drummond, 1993] which are derived in part from slab melting.

Table 5. Representative Electron Microprobe Analyses of Glass

\begin{tabular}{|c|c|c|c|c|c|c|c|c|c|c|c|c|c|c|}
\hline Eruption & $\begin{array}{c}1 \\
\left(\mathrm{SH}_{1964}\right) \\
\end{array}$ & $4\left(\mathrm{SH}_{1}\right)$ & $6\left(\mathrm{SH}_{2}\right)$ & 8 & $11\left(\mathrm{SH}_{3}\right)$ & 12 & 13 & 16 & 22 & 32 & 35 & 44 & 47 & 51 \\
\hline $\mathrm{SiO}_{2}$ & 75.06 & 74.86 & 75.52 & 76.06 & 75.46 & 76.75 & 75.88 & 74.26 & 75.86 & 74.35 & 75.19 & 75.59 & 78.06 & 74.27 \\
\hline $\mathrm{TiO}_{2}$ & 0.25 & 0.24 & 0.26 & 0.23 & 0.24 & 0.26 & 0.26 & 0.23 & 0.22 & 0.33 & 0.23 & 0.22 & 0.17 & 0.35 \\
\hline $\mathrm{Al}_{2} \mathrm{O}_{3}$ & 13.89 & 14.08 & 13.84 & 13.24 & 13.94 & 12.96 & 13.33 & 13.97 & 13.77 & 14.12 & 13.77 & 13.46 & 12.72 & 14.25 \\
\hline $\mathrm{FeO}$ & 1.24 & 1.04 & 1.11 & 0.92 & 1.25 & 1.07 & 1.19 & 1.40 & 1.09 & 1.52 & 1.24 & 1.06 & 0.76 & 1.48 \\
\hline $\mathrm{MnO}$ & 0.03 & 0.03 & 0.01 & 0.04 & 0.02 & 0.01 & 0.02 & 0.03 & 0.03 & 0.04 & 0.02 & 0.02 & 0.01 & 0.03 \\
\hline $\mathrm{MgO}$ & 0.31 & 0.31 & 0.22 & 0.13 & 0.30 & 0.15 & 0.29 & 0.39 & 0.25 & 0.41 & 0.29 & 0.22 & 0.19 & 0.32 \\
\hline $\mathrm{CaO}$ & 1.27 & 1.32 & 1.16 & 0.90 & 1.27 & 0.87 & 1.10 & 1.47 & 1.16 & 1.37 & 1.13 & 0.96 & 0.97 & 1.33 \\
\hline $\mathrm{Na}_{2} \mathrm{O}$ & 5.03 & 4.89 & 4.60 & 4.80 & 4.35 & 4.46 & 4.67 & 5.11 & 4.50 & 4.93 & 4.47 & 5.44 & 4.01 & 4.41 \\
\hline $\mathrm{K}_{2} \mathrm{O}$ & 2.75 & 2.98 & 3.07 & 3.38 & 2.95 & 3.19 & 2.99 & 2.92 & 2.92 & 2.74 & 2.81 & 2.87 & 2.82 & 3.37 \\
\hline $\mathrm{P}_{2} \mathrm{O}_{5}$ & 0.04 & 0.06 & 0.07 & 0.04 & 0.03 & 0.05 & 0.04 & 0.04 & 0.03 & 0.04 & 0.03 & 0.03 & 0.04 & 0.05 \\
\hline $\mathrm{SO}_{2}$ & 0.03 & 0.01 & 0.02 & 0.01 & 0.02 & 0.03 & 0.04 & 0.02 & 0.01 & 0.02 & 0.02 & 0.02 & 0.02 & 0.02 \\
\hline $\mathrm{F}$ & 0.03 & 0.06 & 0.04 & 0.18 & 0.03 & 0.04 & 0.04 & 0.05 & 0.05 & 0.04 & 0.68 & 0.05 & 0.19 & 0.03 \\
\hline $\mathrm{Cl}$ & 0.11 & 0.13 & 0.11 & 0.09 & 0.15 & 0.18 & 0.17 & 0.15 & 0.11 & 0.12 & 0.12 & 0.10 & 0.05 & 0.12 \\
\hline Total & 100.03 & 100.01 & 100.01 & 100.03 & 100.01 & 100.01 & 100.01 & 100.03 & 100.01 & 100.04 & 100.02 & 100.04 & 100.02 & 100.03 \\
\hline
\end{tabular}

Analyses were made by Cameca SX-100 electron microprobe at New Mexico Institute of Mining and Technology. Multiple analyses for the individual pumice clasts were corrected for sodium loss, normalized to $100 \%$ and averaged. Description of the analyzed samples: eruption number (sample number; facies of the deposit). 1 (00K69; ignimbrite); 4 (00K68; ignimbrite); 6 (00K66; ignimbrite); 8 (00K67; ignimbrite); 11 (00K45; ignimbrite); 12 (00K9; fall); 13 (00K64; ignimbrite); 16 (00K65; ignimbrite); 22 (00K62; ignimbrite); 32 (00K21; ignimbrite); 35 (00K27; ignimbrite); 44 (00K31; ignimbrite); 47 (00K32; fall); 51 (00K41; fall). Eruption codes of marker eruptions are given in parentheses. 


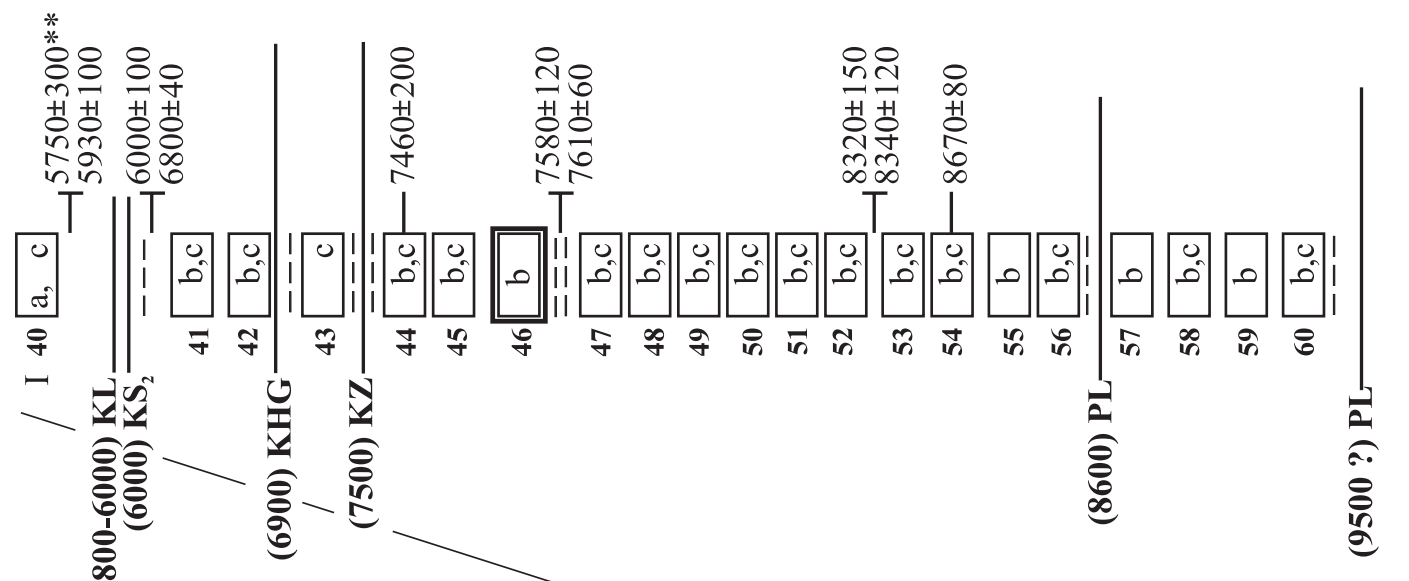

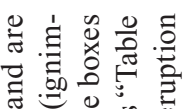

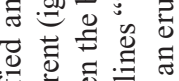

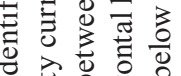

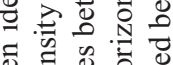

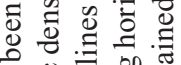
$\circ$.

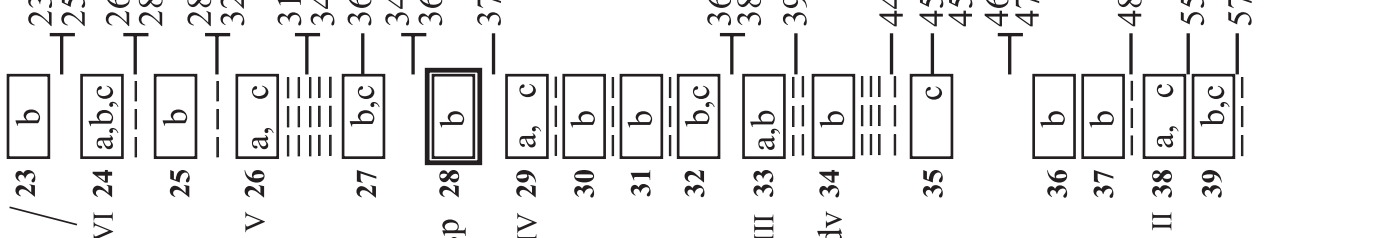

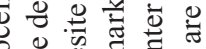

응 巳

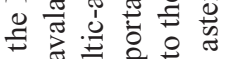

on

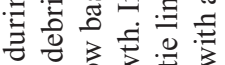

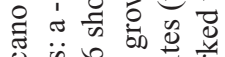
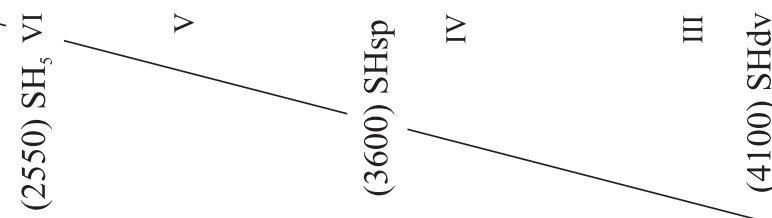

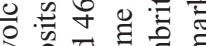

- छ है द्

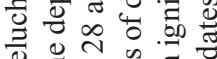

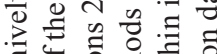
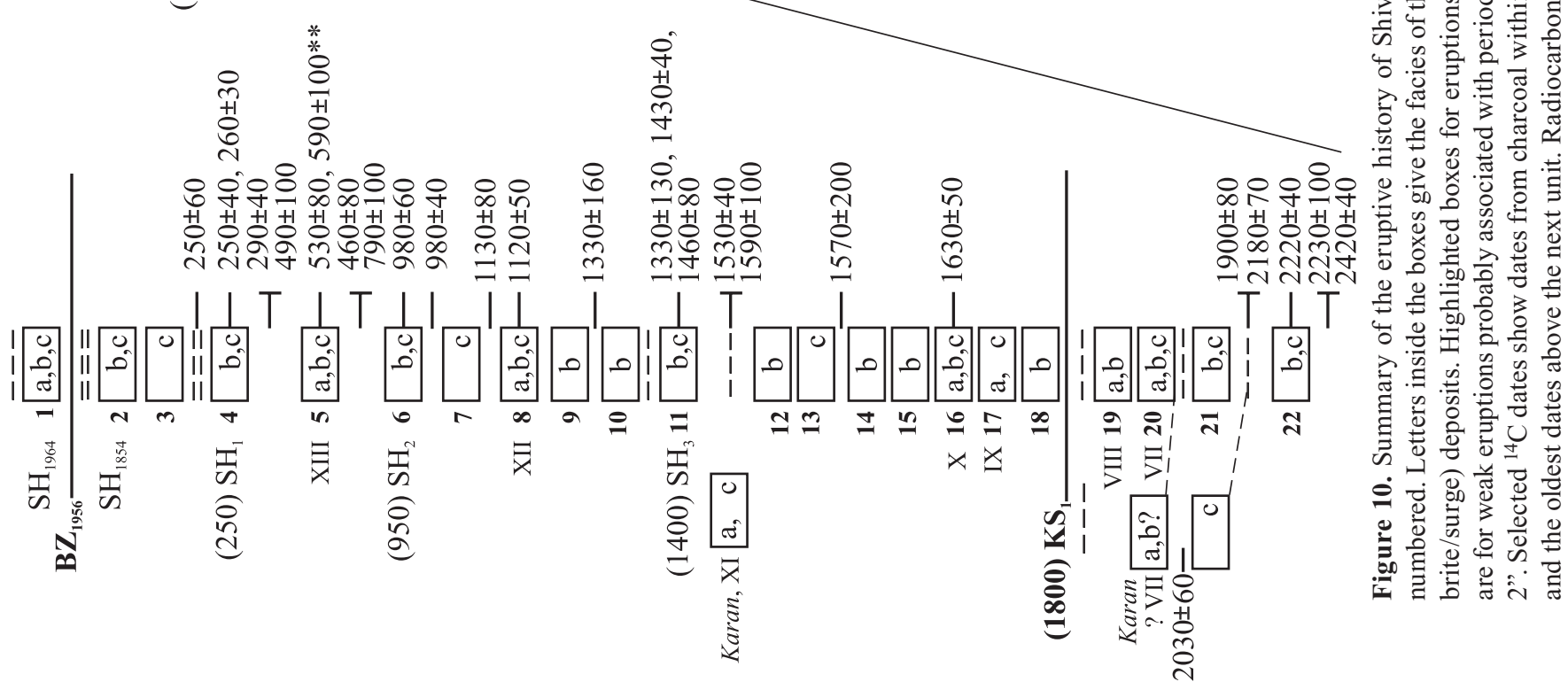

.

+1

ส

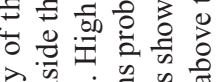

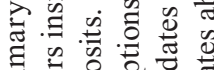

离这运讨

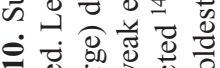

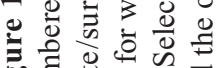

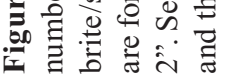


Mafic (56-58\% $\mathrm{SiO}_{2}$ ) members of this sequence are few and are represented both by light-colored pumice and dark-gray scoria. In some cases, lower $\mathrm{SiO}_{2}$ content in the rock coincides with a presence of relatively mafic glass (Fig. 11C; Table 5); it might be interpreted as an input of more mafic material into the magma feeding system. Banded pumices with alternating layers of andesitic and basaltic andesitic material have been described for Shiveluch, that reflects simultaneous presence of both magmas in a chamber [Volynets, 1979]. Other mafic andesite varieties contain silicic glass and their bulk composition might reflect enrichment of andesitic pumice with mineral grains including those from disintegrated ultramafic xenoliths (Fig. 11C) [Volynets et al., 1997]. This latter case resembles changes of Shiveluch tephra composition downwind due to eolian segregation: as it has been described earlier, its bulk composition may change from silicic andesite (proximal pumice lapilli) to basaltic andesite (sand-size tephra enriched in mineral grains) and then again to silicic andesite or dacite (very fine ash) [Braitseva et al., 1997a]. Bulk analyses of lapilli from the andesitic sequence show coherent geochemical trends consistent with fractional crystallization (Fig. 11A); [Volynets et al., 1997]. The Shiveluch tephra have high $\mathrm{MgO}$ (2.3-6.8 wt \%), Cr (47-520 ppm), Ni (18-106 ppm) and Sr (471-615 $\mathrm{ppm})$ and low $\mathrm{Y}(<18 \mathrm{ppm})$.

\section{SHIVELUCH ACTIVITY DURING THE HOLOCENE}

The volume of eruptions from Shiveluch volcano over the last $10 \mathrm{ka}$ are given in Figure 12 . We have arbitrarily assigned a volume of $0.5 \mathrm{~km}^{3}$ for units which have similar thicknesses and distribution to the 1964 deposits. Debris avalanche deposits with unknown or $<1 \mathrm{~km}^{3}$ volumes [Ponomareva et al., 1998] are assigned a volume of $0.5 \mathrm{~km}^{3}$. Periods of dome growth were identified in the stratigraphic record by the presence of the tephra layers similar to those erupted from domes between 1944 and 2005. Typically these consisted of minor pumiceous or lithic-rich coarse tephra fallout, including pink (oxidized) fine and coarse tephra. Five periods of small or infrequent eruptions and low activity are shaded on Figure 12.

The eruptive activity of Shiveluch during the Holocene (Figs. 9, 10 and 12) has been characterized by Plinian eruptions alternating with periods of dome growth. Plinian eruptions with eruption volumes $\geq 0.6-0.8 \mathrm{~km}^{3}$ have occurred at least 23 times during the Holocene giving an average of over 2 Plinian eruptions per 1000 years. At the same time, Shiveluch activity has not been uniform with time. Periods of large and moderate eruptions separated by only $50-100$ years intervals, often were followed by long periods of small eruptions.
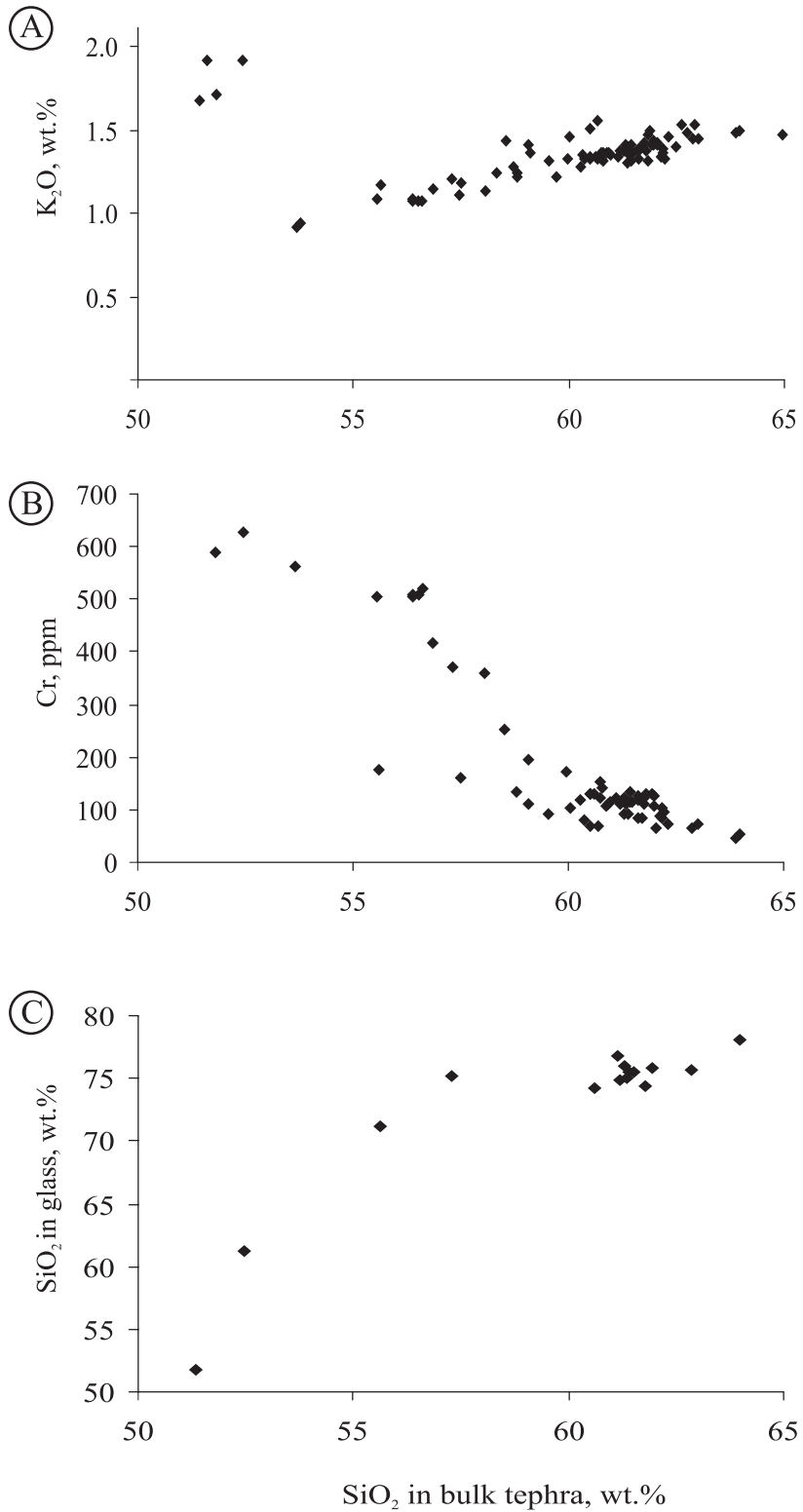

Figure 11. Silica variation diagrams showing $\mathrm{K}_{2} \mathrm{O}$ and $\mathrm{Cr}$ contents in pumice and scoria samples representative of the bulk composition of the erupted tephra. Groundmass glasses are rhyolitic although the parental eruptions were andesitic. The smooth linear trend in the $\mathrm{K}_{2} \mathrm{O}$ plot is consistent with the magmas evolving from a basaltic andesite parent by fractional crystallization. The "basic" ( $52 \%$ $\mathrm{SiO}_{2}$ ) SHsp eruption is more potassic than the evolved andesitic rocks and is not related to the normal andesitic rocks erupted from Shiveluch. See "Table 4" (available on the CD-ROM accompanying this volume) and "Table 5" for the data.

Shiveluch had 3 distinct periods of frequent moderate to large eruptions. These were from $\sim 8500$ to $6400 \mathrm{BC}$, with 16 eruptions; from $\sim 2600$ to $1700 \mathrm{BC}$, with 5 eruptions and since $\sim 900 \mathrm{BC}$ with 16 eruptions including eruptions 
from the Karan domes on the western flank of the volcano. Within these periods there were times when the large and moderate eruptions were only $\sim 50$ years apart. These times were 6500-6400 BC, 2250-2000 BC, and 50-650 AD. Unusual mafic eruptions ("dark package" and SHsp) occurred during the 2 earlier periods. The earliest and the latest periods fit well into periods of intensified activity noted throughout Kamchatka [Braitseva et al., 1995]. The 2250 to $2000 \mathrm{BC}$ activity with the unique SHsp correlates with periods of strong mafic eruptions, documented on many Kamchatka volcanoes, including the growth of the young cones of Avachinsky and Gamchen volcanoes and vigorous activity of flank vents on Kliuchevskoi volcano [Braitseva et al., 1995; Kozhurin et al., 2006].

Long periods with little deposition of tephra $>7 \mathrm{~km}$ from the vent, happened several times in the volcano's life (Fig. 12). The longest quiet period between 6400 and 4600 $\mathrm{BC}$ had only one large plinian eruption at $\sim 5500 \mathrm{BC}$ and intermittent minor activity. The last relatively calm period took place between 1800 and $900 \mathrm{BC}$ with small collapse deposits found in Mutny, Baidarnaia and Dry Il'chinets rivers.

The eruptive frequency of Shiveluch activity was irregular. The current period of activity seems to have started around $900 \mathrm{BC}$; since then the large and moderate eruptions follow each other in 50-400 yrs-long intervals. Over the $\sim 1.5 \mathrm{ka}$ there was at least 5 largest, 3 large, 2 moderate eruptions and 5 debris avalanches including the largest one during the Holocene. This persistent and strong activity can be matched only by the early Holocene one.

Explosive eruptions associated with debris avalanches were small to large, but never the largest (Fig. 12). During some of them explosive events were likely provoked by sector collapses, otherwise the activity might have been restricted to another dome formation as it was shown for the 1964 eruption by Belousov [1995]. Only 2 pre-historic debris avalanches were immediately followed by a large pumice fall similar to the 1964 eruption. In 3 more cases explosive events included moderate to small pumice fall and extensive pyroclastic density currents. In other cases explosive activity was weak. In most cases debris avalanche-associated eruptions did not follow each other but were separated by one or more Plinian eruptions. The largest Plinian eruptions, such as $\mathrm{SH}_{1}$, $\mathrm{SH}_{2}$ and $\mathrm{SH}_{3}$, followed within a 50-200-yrs long intervals after the debris avalanche-associated eruptions.

During the Holocene most Shiveluch eruptions were andesitic (Fig. 12). No other Kamchatka volcano has consistently produced andesite like Shiveluch during the Holocene. Most of other "andesitic" volcanoes, including Bezymianny and Kizimen, also erupted large amounts of mafic material during their lifetime [Braitseva et al., 1991; Melekestsev et al.,
1995]. The persistent andesitic eruptions from Shiveluch suggest the existence of a steady andesitic magma chamber under the volcano. Petrologic models show that the andesite at Shiveluch could fractionate from basaltic andesite. Basaltic andesite has erupted a number of times, most recently in 1854 , but it also occurs as mafic bands in some andesitic pumice [Volynets et al., 1979, 1997]. As it was discussed earlier, two mafic tephras, "dark package" and SHsp, erupted about 6500 and $2000 \mathrm{BC}$, respectively, likely reflect some important events in the magma feeding system, especially the later one, which has no analogues in any other Shiveluch products but has a certain similarity to the basalts of nearby Kharchinsky volcano [Volynets et al., 1997]. There is no distinct relationship between composition of the erupted products and the size of an eruption or its position within the active period. We only can note that the two mafic tephras appeared close to the end of the corresponding periods of activity. Based on seismic data, replenishment of this supposed crustal chamber starts from the depth of at least 100 $\mathrm{km}$ and was registered even before small explosive eruptions [Gorelchik et al., 1997]. Irregularity of Shiveluch activity, correlation of its main peaks with the regional ones, stability of magma composition and replenishment of the crustal chamber from a deep source even before small explosive eruptions suggest that pulses of Shiveluch activity are governed by a deep-seated process.

Shiveluch eruptive history clearly demonstrates that historical activity was far less hazardous than some of the preceding eruptions. The largest historical eruptions (in 1854 and 1964) were not the largest ones on the geological record (Fig. 12), and their tephra fall was dispersed mainly to the north and east, respectively, where the closest villages were located farther than $80 \mathrm{~km}$ from the volcano (Fig. 1). Some 150-200 years before the 1854 eruption a far stronger eruption $\left(\mathrm{SH}_{1}\right)$ occurred, which produced pumice fall and voluminous ignimbrite $>22 \mathrm{~km}$ long, and caused extensive debris flows (lahars) down all the valleys. Pyroclastic density currents were dispersed mostly in the southern sector with minor offshoots into Mutny and II Lednikovy valleys (Fig. 3A, B). Prominent features of deposits on the southern slope are carbonized spruce trunks still standing in an upright position. Fall deposits combine pumice fall and co-ignimbrite fall, and are commonly stratified. The fall dispersal pattern is shown on Figure $5 \mathrm{~B}$. The present day thickness of compacted $\mathrm{SH}_{1}$ tephra in Kliuchi town, $\sim 45 \mathrm{~km}$ to the southwest, is $\sim 4 \mathrm{~cm}$.

The impact of future eruption will depend on the season and snow cover. Future eruptions could result in Plinian eruptive columns which collapse giving pyroclastic density currents. These could ignite a large forest fire and destroy roads and buildings. Tephra falls $\sim 6-8 \mathrm{~cm}$ thick could occur in Kliuchi. Lahars will also descend to the Kamchatka River, 


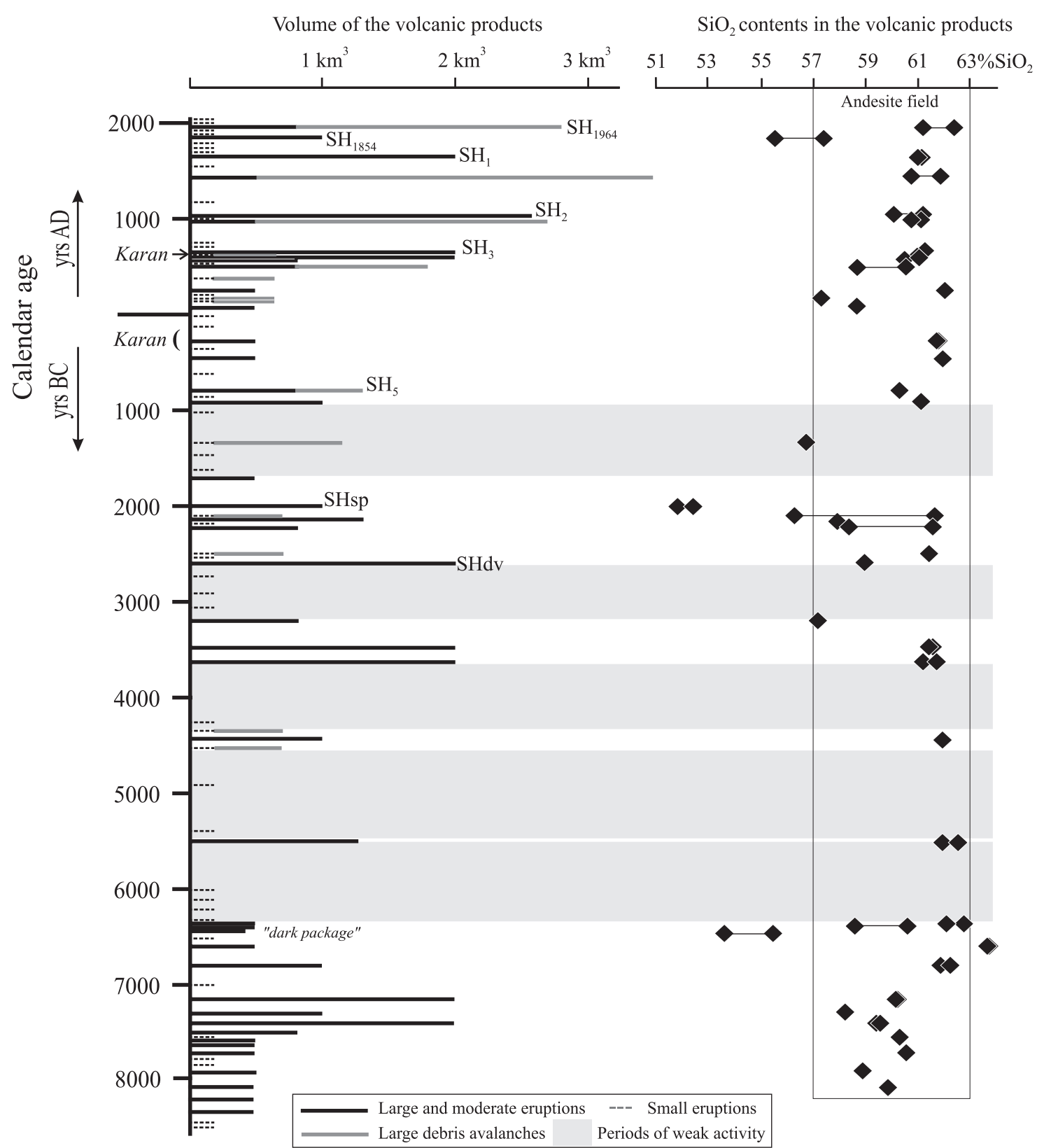

Figure 12. Volumes of eruptive products and the Holocene eruptive history of Shiveluch volcano. Ages are in calendar years AD or BC. Codes of the eruptions as in Table 2. Periods of Karan domes activity are shown to the left of the age axis. The $\mathrm{SiO}_{2}$ contents of the erupted products show most eruptions were andesitic (the range in analyses for the same eruption are shown by tie lines). The figure is based on the data from "Table 3" and "Table 4" (available on the CD-ROM accompanying this volume).

which will bring sediment load down to Ust'-Kamchatsk. A lahar in winter could break ice on the river (as in 1854) and may cause an unexpected ice drift towards the river mouth.

The largest Holocene eruption from Shiveluch was likely $\mathrm{SH}_{2}$, which occurred $\sim 1050 \mathrm{AD}$ and yielded more than 2.5 $\mathrm{km}^{3}$ of tephra. Its pumice fall was dispersed in all the direc- tions from the volcano and can be traced southwards as far as Uzon caldera (Fig. 5C). In Kliuchi, the thickness of a compacted tephra from this eruption $(\sim 9 \mathrm{~cm})$ exceeds that of any other tephra from Shiveluch deposited during the Holocene. Its ignimbrite, on the contrary, is limited to the most proximal area $(<8 \mathrm{~km}$ from the crater). 
The forecast of future large eruptions from Shiveluch, based on its eruptive history, is ambiguous. We noted that since $\sim 900 \mathrm{BC}$ the volcano is in its active period, the longest one in the Holocene (Fig. 12). A number of recent eruptions $\left(\mathrm{SH}_{1}, \mathrm{SH}_{2}, \mathrm{SH}_{3}\right.$ etc.) were the largest in the eruptive history of the volcano. In most cases, debris avalanche-associated eruptions were followed by Plinian eruptions. So after the 1964 eruption, which started from a debris avalanche, we might expect a large to largest Plinian eruption in future. At the same time, it is not clear why past active periods were shorter than the modern one and why they gave way to long periods of weak activity.

\section{CONCLUSIONS}

1) Pyroclastic deposits surrounding Shiveluch volcano show it has been active throughout the Holocene. Eruptive activity has included numerous Plinian eruptions, deposition of debris flows and debris avalanches and periods of lava dome growth. Many past eruptions from Shiveluch, were larger and more hazardous than historical eruptions. The tephra fall of the $\sim 1050 \mathrm{AD}$ eruption $\left(\mathrm{SH}_{2}\right)$ exceeded $2.5 \mathrm{~km}^{3}$. Tephra falls from Shiveluch eruptions often exceeded $350 \mathrm{~km}$ making them good stratigraphic markers.

2) Eruptive activity at Shiveluch alternated between periods of strong and weak activity. Active periods were $\sim 8500$ $6400 \mathrm{BC}, 2600-1700 \mathrm{BC}$ and from $\sim 900 \mathrm{BC}$ to the present. Within these periods there were times when the large and moderate eruptions were $\sim 50$ years apart. These times were 6500-6400 BC, 2250-2000 BC, and 50-650 AD. The oldest and youngest peaks of activity coincide with periods of increased eruptive activity shown by volcanoes throughout Kamchatka. The 2250-2000 BC eruptions may correlate with a period of increased mafic eruptions seen at many Kamchatka volcanoes.

3) The current period of activity started around $900 \mathrm{BC}$ and is the longest in the Holocene. Debris avalanche events were usually followed 50 to $200 \mathrm{yrs}$ later by Plinian eruptions. The 1964 Shiveluch eruption commenced with a debris avalanche so a large Plinian eruption may occur in the near future.

4) During the Holocene Shiveluch has erupted mainly medium-K, hornblende-bearing andesite $\left(56-63 \% \mathrm{SiO}_{2}\right)$ characterized by high $\mathrm{MgO}(2.3-6.8$ wt \%), Cr (47-520 ppm), Ni (18-106 ppm) and Sr (471-615 ppm), and low Y $(<18 \mathrm{ppm})$. Two mafic tephras including a high-K, high-Mg olivine- and phlogopite-bearing basalt were erupted. The mafic eruptions occurred during peaks of activity indicating changes in the magma supply system.

5. In order to better understand magmatic processes under Shiveluch, more mineralogical and geochemical data on the eruptive deposits are necessary. In future studies, analysis of the evolution of tephra compositions with respect to periods of eruptive activity and eruption volume is desirable. Large and largest eruptions from Shiveluch produced tephra layers, which are good markers for Holocene studies. However, most of the Shiveluch tephra have similar bulk, mineral and glass compositions. In order to be able to use them as markers more detailed characterization and geochemical fingerprinting are required.

Acknowledgements. This research was supported by grants \#\# 05-05-64776, 06-05-64960 and 06-05-64960 from the Russian Foundation for Basic Research and NSF grant \#EAR-0125787 to Joanne Bourgeois. The 1999 and 2000-field work was supported by grants \#\# 6543-99 and 6831-00 from the National Geographic Society. We are very grateful to Olga Braitseva who shared her 1978 field data and to Ivan Melekestsev for allowance to use his unpublished map of the Shiveluch deposits. Support from the New Mexico Institute of Mining and Technology helped to cover the field expenses of Melanie Hartman. Philip Kyle acknowledges support from the Office of Polar Programs, NSF. Lab expenses at NMT were partially supported by a grant to $\mathrm{MH}$ from the Geological Society of America. We thank Andrei Babansky (IGEM) for additional analyses of major elements and Dmitry Melnikov for space images processing.

\section{REFERENCES}

Belousov, A. B. (1995), The Shiveluch volcanic eruption of 12 November 1964-explosive eruption provoked by failure of the edifice, J. Volcanol. Geotherm. Res., 66, 357-365.

Belousov, A., Belousova, M., and B. Voight (1999), Multiple edifice failures, debris avalanches and associated eruptions in the Holocene history of Shiveluch volcano, Kamchatka, Russia, Bull. Volcanol., 61, 324-342.

Bourgeois, J., Pinegina, T. K., Ponomareva, V. V., and N. E. Zaretskaia (2006), Holocene tsunamis in the southwestern Bering Sea, Russian Far East and their tectonic implications, The Geol. Soc. Amer. Bull., 11 (3/4), 449-463; doi: 10.1130/B25726.1.

Braitseva, O. A., Melekestsev, I. V., and V. V. Ponomareva (1983), Age divisions of the Holocene volcanic formations of the Tolbachik Valley, The great Tolbachik fissure eruption: geological and geophysical data 1975-1976, Cambrige Earth Sci. Series, 83-95.

Braitseva, O. A., Sulerzhitsky, L. D., Litasova, S.N., Grebzdy E.I. (1988), Radiocarbon dates for the Holocene soil-pyroclastic cover in the Kliuchevskoi volcano group, Volcanol. and Seismol., 6, 317-325.

Braitseva, O. A., Melekestsev, I. V., Bogoyavlenskaya, G. E., and A. P. Maksimov (1991), Bezymianny volcano: eruptive history and activity dynamics, Volcanol. and Seismol., 12(2), 165-194.

Braitseva, O. A., Litasova, S. N., and L. D. Sulerzhitsky (1992), Validity of radiocarbon dating in regions of active volcanism in Kamchatka, Quaternary International, 13/14, 143-146.

Braitseva, O. A., Sulerzhitsky, L. D., Litasova, S. N., Melekestsev, I. V., and V. V. Ponomareva (1993), Radiocarbon dating and tephrochronology in Kamchatka. Radiocarbon 35(3), 463-476. 
Braitseva, O. A., Melekestsev, I. V., Ponomareva, V. V., and L. D. Sulerzhitsky (1995), The ages of calderas, large explosive craters and active volcanoes in the Kuril-Kamchatka region, Russia, Bull. Volcanol., 57(6), 383-402.

Braitseva, O. A., Ponomareva, V. V., Sulerzhitsky, L. D., Melekestsev, I. V., and J. Bailey (1997a), Holocene key-marker tephra layers in Kamchatka, Russia, Quaternary Research, 47(2), 125-139.

Braitseva, O. A., Sulerzhitsky, L. D., Ponomareva, V. V., and I. V. Melekestsev (1997b), Geochronology of the greatest Holocene explosive eruptions in Kamchatka and their imprint on the Greenland glacier shield, Transactions (Doklady) of the Russian Academy of Sciences. Earth science sections, 352(1), 138-140.

Braitseva, O. A., Bazanova, L.I., Melekestsev, I. V., and L.D. Sulerzhitsky (1998) The largest Holocene eruptions of Avachinsky volcano, Kamchatka, Volcanol. and Seismol., 20, 1-27.

Churikova, T., Dorendorf, F., and G. Woerner (2001), Sources and fluids in the mantle wedge below Kamchatka, evidence from across-arc geochemical variation, J. of Petrology, 42(8), $1567-1594$.

Davidson, J. and S. DeSilva (2000), Composite volcanoes. in Sigurdsson, H., ed., Encyclopedia of Volcanoes: San Diego, CA, Academic Press, p. 663-682.

Defant, M.J. and M.S. Drummond (1990), Derivation of some modern arc magmas by melting of young subducted lithosphere, Nature (London), 347, 662-665.

Ditmar, K. (1890), Reisen und Aufenthalt in Kamtschatka in den Jahren 1851-1855. Th. 1. Beitrage zur Kenntniss des Russischen Reiches, Bd. 7, Spb

Dvigalo, V. N. (1984), Growth of the dome in the crater of Shiveluch volcano in 1980-1981 according to photogrammetric data, Volcanol. and Seismol., (2), 104-109 (in Russian).

Fedotov, S.A., Zharinov, N.A., Dvigalo, V.N., Seliverstov, N.I., Khubunaya, S.A. (2004), The 2001-2004 eruptive cycle of Shiveluch volcano, Volcanol. and Seismol., (6), 3-14 (in Russian).

Gill, J. (1981), Orogenic Andesites and Plate Tectonics. Berlin: Springer, $390 \mathrm{pp}$.

Glicken, H. (1986), Rockslide-debris avalanche of May 18, 1980, Mount St. Helens volcano, Washington. The University of California. Santa Barbara, Ph. D. Dissertation, 303.

Gorelchik, V. I., Shirokov, V. A., Firstov, P. P., and O. S. Chubarova (1997), Shiveluch volcano: seismicity, deep structure and forecasting eruptions (Kamchatka), J. Volcanol. Geotherm. Res., $78,121-132$.

Gorshkov, G. S. and Yu. M. Dubik (1970), Gigantic directed blast at Shiveluch volcano (Kamchatka), Bull. Volcanol., 34, 261-288.

Kepezhinskas, P., McDermott, F., Defant, M. J., Hochstaedter, A., Drummond, M. S., Hawkesworth, C. J., Koloskov, A., Maury, R. C., and H. Bellon (1997), Trace element and $\mathrm{Sr}-\mathrm{Nd}-\mathrm{Pb}$ isotopic constraints on a three-component model of Kamchatka Arc petrogenesis, Geochimica et Cosmochimica Acta, 61(3), 577-600.

Khubunaya, S. A., Zharinov, N. A., Muravyev, Ya. D., Ivanov, V. V., Boloyavlenskaya, G. E., Novgorodtseva, T. Yu., Demyanchuk, Yu. V., Budnikov, V. A., and S. M. Fazlullin (1995), 1993 eruption of Shiveluch volcano, Volcanol. and Seismol., 17, 1-20.
Kozhurin, A., Acocella, V., Kyle, P. R., Lagmay, F. M., Melekestsev, I. V., Ponomareva, V. V., Rust, D., Tibaldi, A., Tunesi, A., Corazzato, C., Rovida, A., Sakharov, A., Tengonciang, A., and H. Uy (2006), Trenching active faults in Kamchatka, Russia: paleoseismological and tectonic implications, Tectonophysics, 417: 285-304

Melekestsev, I. V., Braitseva, O. A., Erlich, E. N., and N. N. Kozhemyaka (1974), Volcanic mountains and plains. In: Luchitsky I. V. (Ed.) Kamchatka, Kurile and Commander Islands, pp. 162-234, Nauka Press, Moscow (in Russian).

Melekestsev, I. V., Volynets, O. N., Ermakov, V. A., Kirsanova, T. P., and Yu. P. Masurenkov (1991), Shiveluch volcano. In: Fedotov S. A., Masurenkov Yu. P. (Eds.) Active volcanoes of Kamchatka. 1, pp. 84-92, Nauka Press, Moscow.

Melekestsev, I. V., Ponomareva, V. V., and O. N. Volynets (1995), Kizimen volcano (Kamchatka) - future Mt. St.Helens?, J. Volcanol. Geotherm. Res., 65, 205-226.

Meniailov, A. A. (1955), Shiveluch volcano - geological structure, composition of products and eruptions. Transactions of the Laboratory of Volcanology, USSR Academy of Sciences, 9, 265 pp. (in Russian).

Park, J., Levin, V., Lees, J., Peyton, V., Gordeev, E., and A. Ozerov (2002), A Dangling Slab, Amplified Arc Volcanism, Mantle Flow and Seismic Anisotropy in the Kamchatka Plate Corner. In: Stein S. and Freymueller J. T. (Eds.) Plate Boundary Zones. Geodynamics Series, 30, DOI: 10/1029/030GD18

Pevzner, M. M., Ponomareva, V. V., and I. V. Melekestsev (1998), Chernyi Yar - reference section of the Holocene ash markers at the northeastern coast of Kamchatka, Volcanol. and Seismol., 19(4), 389-406.

Pevzner, M. M., Ponomareva, V. V., and L. D. Sulerzhitsky (2006), Holocene soil-pyroclastic successions of the Central Kamchatka depression: ages, structure, depositional features, Volcanol. and Seismol., 1, 24-38 (in Russian).

Peyton, V., Levin, V., Park, J., Brandon, M., Lees, J., Gordeev, E. and A. Ozerov (2001), Mantle flow at a slab edge: Seismic anisotropy in the Kamchatka Region, Geophysical Research Letters, 28(2), 379-382.

Ponomareva, V. V., Pevzner, M. M., and I. V. Melekestsev (1998), Large debris avalanches and associated eruptions in the Holocene eruptive history of Shiveluch Volcano, Kamchatka, Russia, Bull. of Volcanol., 59, 490-505.

Ponomareva, V. V., Melekestsev, I. V., and O. V. Dirksen (2006), Sector collapses and large landslides on late Pleistocene-Holocene volcanoes in Kamchatka, Russia, J. Volcanol. Geotherm. Res., 158, 117-138.

Stuiver, M., Reimer, P.J., and Reimer, R.W. (2005), CALIB $5.0{ }^{14} \mathrm{C}$ age calibration program, www.calib.org

Volynets, O. N. (1979), Heterotaxitic lavas and pumices on the problem of magma mixing . In: Sobolev, V. S. (Ed.), Problems of Deep Magmatism, pp. 181-197, Nauka Press, Moscow (in Russian).

Volynets, O. N. (1994), Geochemical Types, Petrology, and Genesis of Late Cenozoic Volcanic Rocks from the Kurile-Kamchatka Island-arc System, International Geology Review, 36, 373-405. 
Volynets, O. N., Ponomareva, V. V., and A. D. Babansky (1997), Magnesian basalts of Shiveluch andesite volcano, Kamchatka, Petrology, 5(2), 183-196.

Volynets, O. N., Melekestsev, I. V., Ponomareva, V. V., and J. M. Yogodzinski (1999), Kharchinsky and Zarechnyi volcanoes, unique centers of Late Pleistocene magnesian basalts in Kamchatka: Composition of erupted rocks, Volcanol. and Seismol., 21(1), 45-66.

Volynets, O. N., Babanskii A. D., and Yu. V. Gol'tsman (2000), Variations in Isotopic and Trace-Element Composition of Lavas from Volcanoes of the Northern Group, Kamchatka, in Relation to Specific Features of Subduction, Geochemistry International, 38, 1067-1083.

Yogodzinksi, G. M., Lees, J. M., Churikova, T. G., Dorendorf, F., Woerner, G., and O. N. Volynets (2001), Geochemical evidence for the melting of subducting oceanic lithosphere at plate edges, Nature, 409, 500-504.
Zharinov, N. A., Bogoyavlenskaya, G. E., Khubunaya, S. A., and Yu. V. Demyanchuk (1995), A new eruption cycle of Shiveluch volcano, 1980-1993, Volcanol. and Seismol., 17, 21-30.

Vera Ponomareva, Institute of Volcanology and Seismology, Petropavlovsk-Kamchatsky, Russia

Philip Kyle, Department of Earth and Environmental Science, New Mexico Institute of Mining and Technology, Socorro, New Mexico, USA

Maria Pevzner and Leopold Sulerzhitsky, Geological Institute, Moscow, Russia

Melanie Hartman, Department of Earth and Environmental Science, New Mexico Institute of Mining and Technology, Socorro, New Mexico, USA 